\title{
Cross-national Epidemiology of Panic Disorder and Panic Attacks in the World Mental Health Surveys
}
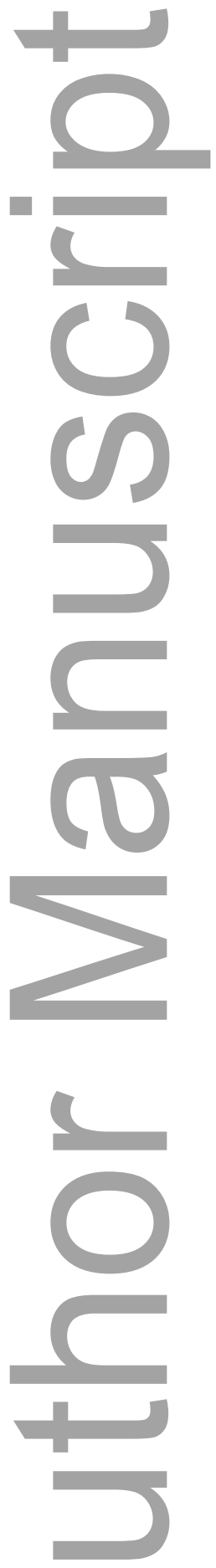

Peter de Jonge, $\mathrm{PhD}^{1}$

Annelieke M. Roest, $\mathrm{PhD}^{1}$

Carmen C.W. Lim, $\mathrm{MSc}^{2}$

Silvia E. Florescu, $\mathrm{MD}, \mathrm{PhD}^{3}$

Evelyn Bromet, $\mathrm{PhD}^{4}$

Dan Stein, $\mathrm{MD}, \mathrm{PhD}^{5}$

Meredith Harris, MPASR, MPH ${ }^{6}$

Vladimir Nakov, $\mathrm{MD}, \mathrm{PhD}^{7}$

Jose Miguel Caldas-de-Almeida, $\mathrm{MD}, \mathrm{PhD}^{8}$

Daphna Levinson ${ }^{9}$

Ali O. Al-Hamzawi, DM, FICMS ${ }^{10}$

Josep Maria Haro, MD, $\mathrm{PhD}^{11}$

Maria Carmen Viana, $\mathrm{MD}, \mathrm{PhD}^{12}$

Gui Borges, $\mathrm{DrSc}^{13}$

Siobhan O’Neill, BA, MPsychSc, $\mathrm{PhD},{ }^{14}$

Giovanni de Girolamo, MD $^{15}$

Koen Demyttenaere, $\mathrm{MD}, \mathrm{PhD}^{16}$

Oye Gureje, $\mathrm{MD}, \mathrm{PhD}^{17}$

Noboru Iwata, $\mathrm{PhD}^{18}$

Sing Lee ${ }^{19}$

This is the author manuscript accepted for publication and has undergone full peer review but has not been through the copyediting, typesetting, pagination and proofreading process, which may lead to differences between this version and the Version of Record. Please cite this article as doi: 10.1002/da.22572. 
Chiyi $\mathrm{Hu}, \mathrm{MD}, \mathrm{PhD}^{20}$

Aimee Karam, $\mathrm{PhD}^{21}$

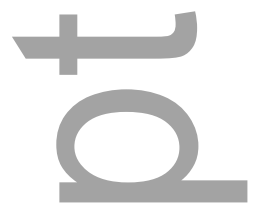

Jacek Moskalewicz, $\mathrm{PhD}^{22}$

Viviane Kovess-Masfety, MSc, $\mathrm{MD}, \mathrm{PhD}^{23}$

Fernando Navarro-Mateu, $\mathrm{MD}, \mathrm{PhD}^{24}$

Mark Oakley Browne, $\mathrm{PhD}^{25}$

Maria Piazza, ScD, $\mathrm{MPH}^{26}$

José Posada-Villa, $\mathrm{MD}^{27}$

Yolanda Torres, MPH, DrHC ${ }^{28}$

Margreet L. ten Have, $\mathrm{PhD}^{29}$

Ronald C. Kessler, $\mathrm{PhD}^{30}$

Kate M. Scott, $\mathrm{PhD}^{2}$

Corresponding author: Peter de Jonge, peter.de.jonge@umcg.nl

${ }^{1}$ University of Groningen, University Medical Center Groningen, Department of Psychiatry, Interdisciplinary Center Psychopathology and Emotion Regulation (ICPE), Groningen, the Netherlands.

${ }^{2}$ Department of Psychological Medicine, Dunedin School of Medicine, University of Otago, Dunedin, New Zealand.

${ }^{3}$ National School of Public Health, Management and Professional Development, Bucharest, Romania.

${ }^{4}$ Department of Psychiatry, Stony Brook University School of Medicine, USA

${ }^{5}$ Department of Psychiatry and Mental Health, University of Cape Town, Cape Town, Republic of South Africa

${ }^{6}$ School of Public Health, University of Queensland, Herston, QLD, Australia

${ }^{7}$ Department of Mental Health, National Center of Public Health and Analyses, Sofia, Bulgaria

${ }^{8}$ Chronic Diseases research Center (CEDOC) and Department of Mental Health, Faculdade de Ciencias Medicas, Universidade Nova de Lisboa, Lisboa, Portugal

${ }^{9}$ Mental Health Services, Ministry of Health Israel, Israel

This article is protected by copyright. All rights reserved. 
${ }^{10}$ College of Medicine, Al-Qadisiya University, Al Diwaniya City, Iraq

${ }^{11}$ CIBERSAM, Parc Sanitari Sant Joan de Deu, Universitat de Barcelona, Barcelona, Spain.

${ }^{12}$ Department of Social Medicine, Federal University of Espirito Santo, Brazil

${ }^{13}$ Instituo Nacional der Psiquiatria, Calzada Mexico Xochimilco, Mexico.

${ }^{14}$ School of Psychology, University of Ulster, Londonderry, United Kingdom

${ }^{15}$ IRCCS Centro S. Giovanni di Dio Fatebenefratelli, Brescia, Italy.

${ }^{16}$ Department of Psychiatry, University Hospital Gasthuisberg, Katholieke Universiteit Leuven, Leuven, Belgium.

${ }^{17}$ Department of Psychiatry, College of Medicine, University of Ibadan, University College Hospital, Ibadan, Nigeria.

${ }^{18}$ Department of Psychology, Hiroshima International University, Hiroshima, Japan.

${ }^{19}$ Department of Psychiatry, The Chinese University of Hongkong, Hongkong, China

${ }^{20}$ Institute of Mental Health, Peking University, Beijing, China.

${ }^{21}$ Institute for Development, Research, Advocacy and applied Care (IDRAAC), Beirut, Lebanon.

${ }^{22}$ Institute of Psychiatry amd Neurology, Warsawa, Poland.

${ }^{23}$ Ecole des Hautes Estudies en Sante Pulbique, Paris Descartes University, Paris, France.

${ }^{24}$ Instituto Murciano de Investigación Biosanitaria (IMIB)-Arrixaca. Centro de Investigación Biomédica en Red. Epidemiología y Salud Pública (CIBERESP)-Murcia. Subdirección General de Salud Mental y Asistencia Psiquiátrica. Servicio Murciano de Salud, El Palmar (Murcia), Spain.

${ }^{25}$ Centre for Mental Health, Melbourne School of Population and Global Health, University of Melbourne, Australia

${ }^{26}$ National Institute of Health, Peru, Universidad Cayetano Hereidia, St Martin de Porres, Peru

${ }^{27} \mathrm{El}$ Bosque University, Bogota, Colombia

${ }^{28}$ Center for Excellence on Research in Mental Health, CES University, Medellin, Colombia

${ }^{29}$ Trimbos Instituut, Netherlands Institute of Mental Health and Addiction, Utrecht, Netherlands

${ }^{30}$ Department of Health Care Policy, Harvard University Medical School, Boston, USA

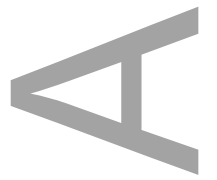

This article is protected by copyright. All rights reserved. 


\section{Funding information:}

The World Health Organization World Mental Health (WMH) Survey Initiative is supported by the National Institute of Mental Health (NIMH; R01 MH070884), the John D. and Catherine T. MacArthur Foundation, the Pfizer Foundation, the US Public Health Service (R13-MH066849, R01MH069864, and R01 DA016558), the Fogarty International Center (FIRCA R03-TW006481), the Pan American Health Organization, Eli Lilly and Company, Ortho-McNeil Pharmaceutical, GlaxoSmithKline, and Bristol-Myers Squibb. None of these funders had any role in the design, analysis, interpretation of results, or preparation of this article. A complete list of all within-country and cross-national WMH publications can be found at http://www.hcp.med.harvard.edu/wmh/.

Each WMH country obtained funding for its own survey. The São Paulo Megacity Mental Health Survey is supported by the State of São Paulo Research Foundation (FAPESP) Thematic Project Grant 03/00204-3. The Bulgarian Epidemiological Study of common mental disorders EPIBUL is supported by the Ministry of Health and the National Center for Public Health Protection. The Chinese World Mental Health Survey Initiative is supported by the Pfizer Foundation. The Shenzhen Mental Health Survey is supported by the Shenzhen Bureau of Health and the Shenzhen Bureau of Science, Technology, and Information. The Colombian National Study of Mental Health (NSMH) is supported by the Ministry of Social Protection. The Mental Health Study Medellín Colombia was carried out and supported jointly by the Center for Excellence on Research in Mental Health (CES University) and the Secretary of Health of Medellín. The ESEMeD project is funded by the European Commission (Contracts QLG5-1999-01042; SANCO 2004123, and EAHC 20081308), (the Piedmont Region (Italy)), Fondo de Investigación Sanitaria, Instituto de Salud Carlos III, Spain (FIS 00/0028), Ministerio de Ciencia y Tecnología, Spain (SAF 2000-158-CE), Departament de Salut, Generalitat de Catalunya, Spain, Instituto de Salud Carlos III (CIBER CB06/02/0046, RETICS RD06/0011 REM-TAP), and other local agencies and by an unrestricted educational grant from GlaxoSmithKline. Implementation of the Iraq Mental Health Survey (IMHS) and data entry were carried out by the staff of the Iraqi MOH and MOP with direct support from the Iraqi IMHS team with funding from both the Japanese and European Funds through United Nations Development Group Iraq Trust Fund (UNDG ITF). The World Mental Health Japan (WMHJ) Survey is supported by the Grant for Research on Psychiatric and Neurological Diseases and Mental Health (H13-SHOGAI-023, H14-TOKUBETSU-026, H16-KOKORO-013) from the Japan Ministry of Health, Labour and Welfare. The Lebanese National Mental Health Survey (L.E.B.A.N.O.N.) is supported by the Lebanese Ministry of Public Health, the WHO (Lebanon), National Institute of Health/Fogarty International Center (R03 TW006481- 01), Sheikh Hamdan Bin Rashid Al Maktoum Award for Medical Sciences, anonymous private donations to IDRAAC, Lebanon, and unrestricted grants from AstraZeneca, Eli Lilly, GlaxoSmithKline, Hikma Pharmaceuticals, Janssen Cilag, Lundbeck, Novartis, and Servier. The Mexican National Comorbidity Survey (MNCS) is supported by The National Institute of Psychiatry Ramon de la Fuente (INPRFMDIES 4280) and by the National Council on Science and Technology (CONACyT-G30544- H), with supplemental support from the PanAmerican Health Organization (PAHO). Dr Benjet has received funding from the (Mexican) National Council of Science and Technology (grant CB-2010-01-155221). Te Rau Hinengaro: The New Zealand Mental Health Survey (NZMHS) is supported by the New Zealand Ministry of Health, Alcohol Advisory Council, and the Health Research Council. The Nigerian Survey of Mental Health and Wellbeing (NSMHW) is supported by the WHO (Geneva), the WHO (Nigeria), and the Federal 
Ministry of Health, Abuja, Nigeria. The Northern Ireland Study of Mental Health was funded by the Health \& Social Care Research \& Development Division of the Public Health Agency. The Peruvian World Mental Health Study was funded by the National Institute of Health of the Ministry of Health of Peru. The Polish project Epidemiology of Mental Health and Access to Care -EZOP Poland was carried out by the Institute of Psychiatry and Neurology in Warsaw in consortium with Department of Psychiatry-Medical University in Wroclaw and National Institute of Public Health-National Institute of Hygiene in Warsaw and in partnership with Psykiatrist Institut Vinderen - Universitet, Oslo. The project was funded by the Norwegian Financial Mechanism and the European Economic Area Mechanism as well as Polish Ministry of Health. No support from pharmaceutical industry neither other commercial sources was received. The Portuguese Mental Health Study was carried out by the Department of Mental Health, Faculty of Medical Sciences, NOVA University of Lisbon, with collaboration of the Portuguese Catholic University, and was funded by Champalimaud Foundation, Gulbenkian Foundation, Foundation for Science and Technology (FCT) and Ministry of Health. The Romania WMH study projects "Policies in Mental Health Area" and "National Study regarding Mental Health and Services Use" were carried out by the National School of Public Health \& Health Services Management (former National Institute for Research \& Development in Health), with technical support of Metro Media Transilvania, the National Institute of Statistics-National Centre for Training in Statistics, SC, Cheyenne Services SRL, Statistics Netherlands and were funded by Ministry of Public Health (former Ministry of Health) with supplemental support of Eli Lilly Romania SRL. The South Africa Stress and Health Study (SASH) is supported by the US National Institute of Mental Health (R01-MH059575) and National Institute of Drug Abuse with supplemental funding from the South African Department of Health and the University of Michigan. The Psychiatric Enquiry to General Population in Southeast Spain - Murcia (PEGASUS-Murcia) Project has been financed by the Regional Health Authorities of Murcia (Servicio Murciano de Salud and Consejería de Sanidad y Política Social) and Fundación para la Formación e Investigación Sanitarias (FFIS) of Murcia. The Ukraine Comorbid Mental Disorders during Periods of Social Disruption (CMDPSD) study is funded by the US National Institute of Mental Health (RO1-MH61905). The US National Comorbidity Survey Replication (NCS-R) is supported by the National Institute of Mental Health (NIMH; U01-MH60220) with supplemental support from the National Institute of Drug Abuse (NIDA), the Substance Abuse and Mental Health Services Administration (SAMHSA), the Robert Wood Johnson Foundation (RWJF; Grant 044708), and the John W. Alden Trust. Dr Stein is supported by the Medical Research Council of South Africa (MRC). Preparation of this report was supported by a VICI grant (no: 91812607) received by Peter de Jonge from the Netherlands Research Foundation (NWO-ZonMW).

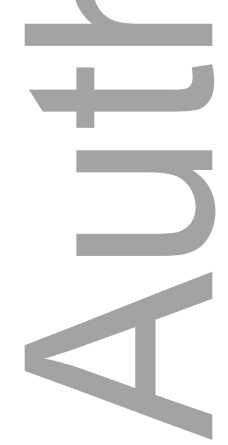

This article is protected by copyright. All rights reserved. 


\section{Acknowledgements}

The authors appreciate the helpful contributions to $\mathrm{WMH}$ of Herbert Matschinger, $\mathrm{PhD}$.

\section{Disclosures}

In the past three years, Dr. Kessler has been a consultant for Hoffman-La Roche, Inc., Johnson \& Johnson Wellness and Prevention, and Sonofi-Aventis Groupe. Dr. Kessler has served on advisory boards for Mensante Corporation, Plus One Health Management, Lake Nona Institute, and U.S. Preventive Medicine. Dr. Kessler is a co-owner of DataStat, Inc. Dr. Demyttenaere is on the speaker bureau for Astra Zeneca, Eli Lilly, Lundbeck and Servier and has received research grants from Eli Lilly, from the foundation 'Ga voor Geluk' and from the Flemish Research Council. In the past three years, Dr. Stein has received research grants and/or consultancy honoraria from AMBRF, Biocodex, Cipla, Lundbeck, National Responsible Gambling Foundation, Novartis, Servier and Sun. The other authors report no disclosures.

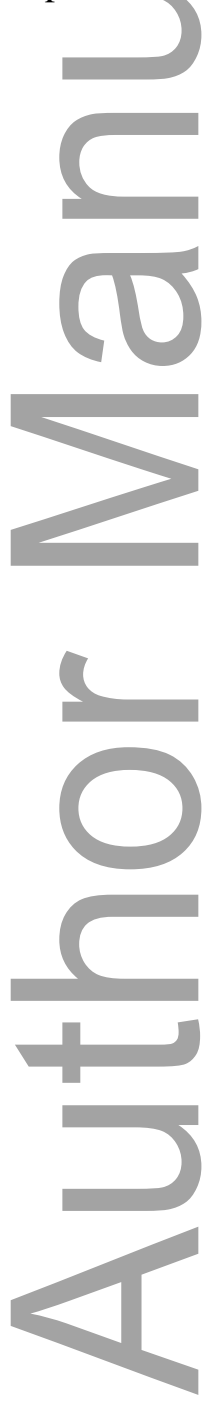

This article is protected by copyright. All rights reserved. 


\begin{abstract}
Context: The scarcity of cross-national reports and the changes in DSM-5 regarding panic disorder (PD) and panic attacks (PAs) call for new epidemiological data on PD and PAs and its subtypes in the general population.
\end{abstract}

Objective: To present representative data about the cross-national epidemiology of PD and PAs in accordance with DSM-5 definitions.

Design and Setting: Nationally representative cross-sectional surveys using the World Health Organization Composite International Diagnostic Interview version 3.0.

Participants: Respondents $(\mathrm{n}=142,949)$ from 25 high, middle and lower-middle income countries across the world aged 18 years or older.

Main Outcome Measures: PD and presence of single and recurrent PAs.

Results: Lifetime prevalence of PAs was $13.2 \%$ (s.e. $0.1 \%$ ). Among persons that ever had a PA, the majority had recurrent PAs (66.5\%; s.e. $0.5 \%$ ), while only $12.8 \%$ fulfilled DSM-5 criteria for PD. Recurrent PAs were associated with a subsequent onset of a variety of mental disorders (OR 2.0; 95\% CI 1.8-2.2) and their course (OR 1.3; 95\% CI 1.2-2.4) whereas single PAs were not (OR 1.1; 95\% CI 0.9-1.3 and OR 0.7; 95\% CI 0.6-0.8). Cross-national lifetime prevalence estimates were $1.7 \%$ (s.e. $0.0 \%$ ) for PD with a median age of onset of 32 (IQR 20-47). Some $80.4 \%$ of persons with lifetime PD had a lifetime comorbid mental disorder.

Conclusions: We extended previous epidemiological data to a cross-national context. The presence of recurrent PAs in particular is associated with subsequent onset and course of mental disorders beyond agoraphobia and PD, and might serve as a generic risk marker for psychopathology.

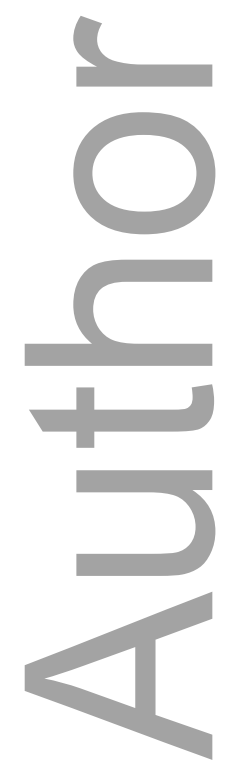

This article is protected by copyright. All rights reserved. 


\section{Introduction}

Anxiety disorders are among the major contributors to the worldwide burden of disease $(1,2)$. Among the anxiety disorders, panic disorder (PD) defined by the presence of recurrent, unexpected panic attacks (PAs) is of specific interest. However, epidemiological data regarding PD and PAs is limited and only few available studies have distinguished between PAs and PD, and within PAs, between single versus recurrent attacks $(3,4)$. Also, most of the available epidemiological data comes from studies performed solely in the US (5-9), but it is especially important to study the characteristics of PD and PA cross-nationally given the evidence that the prevalence of PD differs substantially across cultures (10). In the only cross-national account, that took place more than 20 years ago, only PD (using DSM-III criteria) and not PAs were studied (10).

In a review of the literature by Craske et al (4), several recommendations were made regarding the diagnostic criteria for PAs and PD, which were followed to a large extent in the Diagnostic and Statistical Manual version 5 (DSM-5). Importantly, the diagnosis of PD became no longer linked to the presence or absence of agoraphobia (AGO) as was done in DSM-IV. Also, the presence of PAs in DSM-5 was reframed as a generic symptom specifier that can be added to each of the diagnoses in DSM-5 and thus became no longer restricted to PD or AGO (3). This change was based among others on a series of studies suggesting PAs being associated with many mental disorders (e.g. anxiety and mood disorders, psychosis and substance abuse) and not with PD or AGO alone $(4,12)$. Also, the presence of PAs was found to increase symptom severity, comorbidity rates and suicide, while negatively impacting treatment response in a number of disorders (4).

These changes regarding PD and PAs in DSM-5 call for new epidemiological data . In the present study we report on data regarding the epidemiology of PD from 25 lower-middle, middle, and high income countries. In addition, we report on data regarding PAs and their association with onset and course of mental disorders as this will further inform us about the utility of PAs as a risk marker for psychopathology. We specifically distinguished between single and recurrent PAs in this context as only very few studies are available on this issue. Given the importance of worrying about next PAs, we expected that particularly recurrent PAs would be associated with onset and course of mental disorders, in line with the DSM-IV field trial by Horwath et al (12). We used data from the World Mental Health Surveys (13).

This article is protected by copyright. All rights reserved. 


\section{Method}

Samples

The WMH surveys included data from the low/lower-middle income countries of Colombia, Iraq, Nigeria, Peru, the People's Republic of China - Beijing and Shanghai, and Ukraine, the upper-middle income countries of Brazil, Bulgaria, Colombia (Medellin), Lebanon, Mexico, and Romania, and the high income countries of Australia, Belgium, France, Germany, Israel, Italy, Japan, New Zealand, Northern Ireland, Poland, Portugal, Spain, Spain - Murcia, the Netherlands, and the United States. Most surveys used stratified multistage clustered area probability household sampling with no substitution for non-participants. Data collection took place between 2001 and 2012, and response rates ranged from 45.9 to $97.2 \%$, with an average of $69.0 \%$ (Table 1). Classification of countries into income categories (low-lower, upper-middle, high) was based on World Bank criteria (14).

\section{INSERT TABLE 1}

\section{Assessment of mental disorders}

All WMH surveys were conducted face-to-face by lay interviewers who had received standardized training. Standardized translation, back-translation, harmonization and quality control procedures were applied for each of the participating surveys $(13,15)$. Informed consent was obtained according to protocols endorsed by local Institutional Review Boards. The presence of mental disorders was assessed using the World Health Organization (WHO) Composite International Diagnostic Interview (CIDI) version 3.0. All respondents completed Part 1 of the WHO CIDI (13) which assesses lifetime mood disorders (major depressive episode and/or dysthymia, bipolar disorder), anxiety disorders (panic disorder, agoraphobia, specific phobia, social phobia, generalized anxiety disorder, posttraumatic stress disorder), substance use disorders (alcohol and drug abuse with or without dependence) and impulse control disorder (intermittent explosive disorder, binge-eating disorder and bulimia nervosa). Diagnostic hierarchy and organic exclusion rules were applied for all diagnoses other than substance abuse (with or without dependence). A probing strategy was used to assess age 
of onset for each of the disorders (15). A blinded clinical reappraisal study using the Structured Clinical Interview for DSM-IV (SCID) (16) found good diagnostic concordance between CIDI and SCID diagnoses. For panic disorder, this was indicated by an area under the curve of 0.72 (17).

Part I data were weighted to adjust for the differential probability of being selected and the sociodemographic and geographic structure of each sample. Respondents with a Part I disorder and an additional probability sub-sample were administered Part II of the survey, which assessed a number of other disorders and correlates. Further weightings were applied to the Part II data to adjust for the differential selection procedure and to match base population distributions on socio-demographic and geographic data.

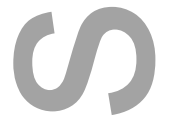

\section{Panic attacks in DSM-IV and DSM-5}

In DSM-IV (18), criteria for PA consisted of a discrete period of intense fear or discomfort, in which four (or more) of the following symptoms develop abruptly and reach a peak within 10 minutes:1) palpitations, pounding heart, or accelerated heart rate, 2) sweating, 3) trembling or shaking, 4) sensations of shortness of breath or smothering, 5) feeling of choking, 6) chest pain or discomfort, 7) nausea or abdominal distress, 8) feeling dizzy, unsteady, lightheaded, or faint, 9) derealization (feelings of unreality) or depersonalization (being detached from oneself), 10) fear of losing control or going crazy, 11) fear of dying, 12) paresthesias (numbness or tingling sensations), 13) chills or hot flushes. PAs were not distinguished as a codable disorder, but only coded in the specific diagnosis in which the PA occurred (e.g. panic disorder with agoraphobia).

In DSM-5, the essential features of the PA specifier remained unchanged, although the DSM-IV terminology for describing different types of PAs (i.e., situationally bound/cued, situationally predisposed, and unexpected/uncued) was replaced with the terms unexpected (out of the blue) and expected PA. PAs function as a specifier and prognostic factor for severity of diagnosis, course, and comorbidity across an array of disorders, including but not limited to anxiety disorders. Hence, PAs can be listed as a specifier applicable to any of the DSM-5 disorders. In the CIDI 3.0, the presence of panic attacks was probed before the diagnosis of $\mathrm{PD}$, as was information on whether the attacks were single or recurrent, expected or unexpected, therefore PAs could be unlinked from PD.

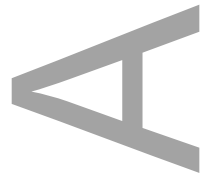

This article is protected by copyright. All rights reserved. 
In DSM-IV, diagnostic criteria for Panic Disorder With or Without Agoraphobia include (1) recurrent, unexpected PAs and (2) at least one of the attacks has been followed by 1 month (or more) of one (or more) of the following: (a) persistent concern about having additional attacks, (b) worry about the implications of the attack or its consequences (e.g., losing control, having a heart attack, "going crazy"), (c) a significant change in behavior related to the attacks. In addition, it is coded whether PD occurred in the presence or absence of agoraphobia. Finally, it is checked that PAs are not due to the direct physiological effects of a substance (e.g., a drug of abuse, a medication) or a general medical condition (e.g., hyperthyroidism), and whether PAs are not better accounted for by another mental disorder, such as social phobia (e.g., occurring on exposure to feared social situations), specific phobia (e.g., on exposure to a specific phobic situation), obsessive-compulsive disorder (e.g., on exposure to dirt in someone with an obsession about contamination), posttraumatic stress disorder (e.g., in response to stimuli associated with a severe stressor), or separation anxiety disorder (e.g., in response to being away from home or close relatives).

In DSM-5, diagnostic criteria were changed in that PD and agoraphobia are unlinked. Essentially, the former DSM-IV diagnoses of PD with agoraphobia, PD without agoraphobia, and agoraphobia without history of PD have been replaced by two diagnoses, PD and agoraphobia, each with separate criteria. DSM-5 PD consists of the presence of recurrent unexpected panic attacks, as defined previously. The additional criteria regarding concerns, maladaptive behaviors and exclusion criteria (due to physiological effects or better explained by other mental disorders) were somewhat reworded but largely kept in line with DSM-IV. In CIDI 3.0, since the criteria regarding PD and agoraphobia were scored first and the specific diagnoses were made later, PD could be unlinked from agoraphobia to arrive at DSM-5 compatible PD diagnosis.

\section{Socio-demographic variables}

Socio-demographic variables included age at interview, ages of onset of PA and PD, sex, education, employment status, marital status, and household income based on country-specific quartiles of gross household earnings in the past 12 months (19). 


\section{Statistical analysis}

We determined rates of lifetime PAs split into persons with and without lifetime PD. Among persons with lifetime PAs without lifetime PD, we distinguished between persons with single and recurrent PAs. Of persons with lifetime diagnosis of PD and of those with a lifetime presence of PAs, we determined the proportion of persons with 12-month prevalence of PD and PAs, as an indicator of the chronicity of PD and PAs. Similarly, persons with 12-month prevalent PD and PAs were split into persons with and without 30-day prevalence of PD and PAs.

Prevalence rates were compared across countries, World Bank income groups, and WHO regions using the Chi-square test of homogeneity. In addition, the estimated proportion of the population who will have the disorder at age 75 (projected risk) was calculated using survival analysis on the basis of age of onset data (except for four of the surveys were age was restricted to 18-65). Specific analyses comparing single yersus recurrent PAs in their association with other (phobic) disorders were done. For analyses examining whether PAs predict onset and course of psychiatric disorders, we used PAs in the absence of $P D$, as otherwise they would count as being part of a comorbid psychiatric disorder (PD).

Logistic regression and survival analyses were used to examine sociodemographic correlates. Survival analysis was used to estimate age of onset (AOO) and projected lifetime risk. The actuarial method implemented in SAS 9.4 was used to generate the AOO curves. Significance was calculated using Wald and McNemar's Chi-square tests. Because the data were weighted and clustered, the Taylor series linearization method (20) implemented in the SUDAAN software package (11.0) (21) was used to estimate design-based standard errors. Statistical significance was consistently evaluated using twosided tests, with $\mathrm{P}<0.05$ considered significant.

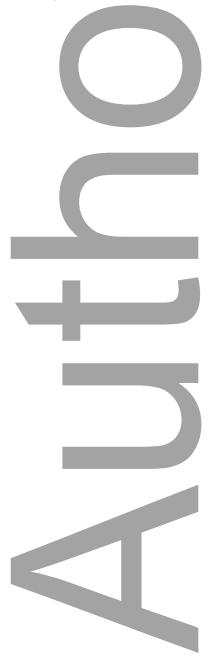

This article is protected by copyright. All rights reserved. 


\section{Results}

Prevalence, age of onset, and lifetime risk of $P A$ and $P D$

Lifetime prevalence of PAs for all countries combined was 13.2\% (se. 0.1\%) (Table 2). Of the persons with lifetime PA, $12.8 \%$ had lifetime PD, for a population-level lifetime prevalence of PD of $1.7 \%$ (se. $0.0 \%$ ) (i.e., $12.8 \%$ x13.2\%). Of persons with lifetime PA without PD, about two thirds $(66.5 \%$; se. $0.5 \%)$ had recurrent PAs.

Significant differences in prevalence rates of PAs and PD were observed between country groups based on income level and on WHO regions, with higher prevalence rates in high income countries and countries in the region of the Americas, Western Pacific and Western Europe. Twelve month prevalence rates of PAs and PD were $4.9 \%$ (se. $0.1 \%$ ) and $1.0 \%$ (se. $0.0 \%$ ) respectively (appendix Table 1). Some $34.5 \%$ (se. $0.5 \%$ ) of persons with lifetime PAs without lifetime PD had PAs in the last twelve months. For PD, this figure was $57.1 \%$ (se. 1.3\%). Prevalence rates for last 30 days PAs and PD were $1.6 \%$ (se. $0.0 \%$ ) and $0.4 \%$ (se. $0.0 \%$ ) respectively. Of persons with past 12 months prevalence of PAs without PD, 29.2\% (se. 0.7\%) had PAs in the last 30 days. For PD, this figure was 40.6\% (se. 1.7\%)(Appendix Table 2). Median age of onset of PAs was 34 years (IQR 20-51) and for PAs without PD this was 35 years (IQR 20-52), resulting in a projected risk at age 75 of $23.0 \%$ (se. 0.4) for PAs and $20.6 \%$ (se. 0.4) for PAs without PD. Median age-of-onset of PD was 32 years (IQR 20-47). The age-of-onset distribution resulted in a projected risk of PD at age 75 of $2.7 \%$ (se. $0.1 \%$ ).

\section{INSERT TABLE 2 ABOUT HERE}

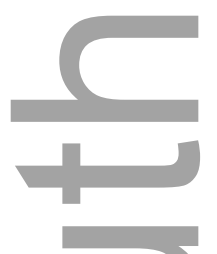

Lifetime co-morbidity with other mental disorders in persons with lifetime PD was $80.4 \%$ (se. $1.1 \%$ ) (Appendix table 3). Co-morbidity levels were particularly high for other anxiety disorders $(63.1 \%$, se $1.3 \%$ ) and mood disorders (53.7\%, se $1.4 \%$ ), and considerably lower for substance abuse disorders (26.2\% se $1.4 \%)$ and impulse controls disorders (10.4\%, se $0.7 \%)$. In persons with lifetime co- 
morbidity, onset of PD preceded the onset of the other disorders in a minority of cases $(15.4 \%$, se. $0.9 \%)$.

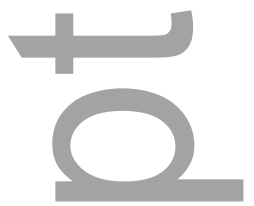

Socio-demographic correlates of PA and PD

Beloning to groups below 60, early age of onset, female gender, other employment status (largely unemployed), being divorced/separated/widowed, lower education, and having a low household income were associated with both PAs without PD and with PD (Appendix Tables 4 and 5). These correlates were largely comparable for the different income level country groups. Few differences were found when comparing risk factors for 30-day, lifetime, 12-month prevalence among lifetime, and 30-days prevalence among 12 months cases, suggesting that largely the same risk factors may operate for onset and course of PAs and PD. However, as an exception, gender was found to be related to onset of PAs and PD, but not to 30-day prevalence among those with a 12-month prevalent disorder.

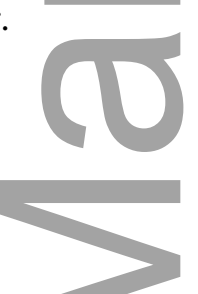

\section{PAs as a predictor of subsequent mental disorder onset and disorder course}

In Table 3, we distinguished between single and recurrent PAs. Single PAs were generally not associated with subsequent mental disorders, with only some exceptions. In contrast, recurrent PAs were associated with increased odds of all included mental disorders. A comparable pattern of results, though less pronounced, emerged when predicting the rates of 12-month cases among lifetime cases per disorder in order to estimate the associations of PAs with course of disorder. Here we found that single PAs appear generally slightly protective while recurrent PAs were associated with a worsened course.

\section{INSERT TABLE 3 ABOUT HERE}

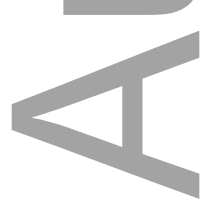

This article is protected by copyright. All rights reserved. 


\section{Discussion}

The goal of this study was to present the cross-national epidemiology of PAs and PD. The general findings were that DSM-5 lifetime prevalence for PD is $1.7 \%$ and its projected lifetime risk at age 75 is $2.7 \%$. These findings are in line with previous cross-national estimates of $1.4-2.9 \%$ (11), while estimates based on American data alone were slightly higher than ours: 4.8\%, 3.4\% and 2.2\% (7-9). The present study extends these findings to 25 countries spread over several regions in the world and income groups. Significant variation in prevalence between countries was observed and this seemed to be both related to income differences and to regional differences. Consistent with previous reports $(6,22,23)$, high levels of comorbidity were found for persons with PD. In the present study, as many as $80.4 \%$ of persons with lifetime PD had a lifetime comorbid other mental disorder, particularly mood or anxiety disorder, and in only a minority of persons did PD precede the onset of any other disorder (15.4\%). Previous reports have found panic as a comorbid disorder to be related to an adverse course of other mental disorders (24).

The lifetime prevalence of PAs was $13.2 \%$ in our sample, with a projected risk at age 75 of $23.0 \%$, making the presence of PAs a common phenomenon in the general population, as observed earlier $(25,26)$. Still, these figures are lower than a previous report based on American data alone (7) (28.3\%). Consistent with these findings however, in our cross-national sample, highest lifetime prevalence rates were found for the United States (27.3\%) and New Zealand (27.4\%). Comparable to the previous report on US data, most PAs occur in the absence of PD: $20.6 \%$ out of $23.0 \%$.

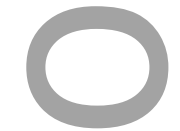

Among persons that ever had a PA, the majority had recurrent PAs. Of interest, recurrent PAs were associated with a subsequent onset of a variety of mental disorders whereas single PAs were not. Also, only recurrent PAs were associated with higher rates of past 12 month disorders among persons with lifetime disorders. This pattern was seen for all mental disorders combined, and specifically for major depression/dysthymia and drug dependence. These findings seem to suggest that particularly the presence of recurrent PAs may be seen as a risk marker for general psychopathology - a suggestion made earlier with respect to PAs in general (12). This finding is of interest as in the review by Craske et al (2010), which served as the evidence base for the suggestion to use PAs as a generic specifier in DSM-5, it was stated that the issue is whether the presence of PAs would "predict 
treatment response, comorbidity or course of mental disorder". In this study, we were able to address the latter two points and found that this seems to hold only for recurrent PAs.

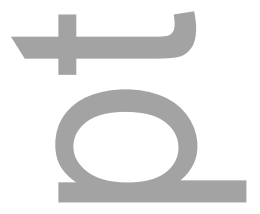

The results of this study should be considered within the context of the following limitations and strengths. The WMH Surveys are essentially cross-sectional in nature and the retrospective assessment of mental disorders and their age of onset is likely to have resulted in inaccuracies in the prevalence of PAs and PD and the age of their onset. Although probing of age of onset was performed on the basis of validated techniques that facilitate accurate recall (27), some bias may have been introduced, probably in the form of underestimation (28). This may particularly be true for PAs which do not have the status of mental disorders and as such are not as extensively probed by multiple items, and their associated disability and treatment status was not scored. In this study, of the persons that ever experienced a PA, 9.1\% were not able to remember if they had single or recurrent PAs. We could therefore not address the point was would be the optimal cut-off for the number of PAs to predict later onset of mental disorders. Also, we could not address other subtypes of PAs to refine the PA specifier in DSM-5, such as symptom-based (29) or age of onset-based subtypes (30). Future research could address the utility of distinguishing between single versus recurrent PAs, and expected versus unexpected PAs, and symptom-based subtypes of PAs in terms of their associated disability and treatment status. Among the strengths of this study, the WMH surveys consist of cross-national samples whereas most reports have been based on a single, national study. This offered the possibility to look into differences between countries, and between groups of countries based on income levels and regions in the world. This strategy has resulted in a large sample of respondents that enabled us to explore in more detail specific subgroups of persons, such as those having PAs in the absence of PD and further dissection into the kind of PAs, without encountering power issues.

In sum, in this study we provided cross-national epidemiological data on DSM-5 PD and PAs, and found a cross-national lifetime prevalence of PD of $1.7 \%$ and an estimated risk at age 75 of $2.7 \%$. For PAs, these figures were $13.2 \%$ and $23.0 \%$ respectively. We found that about two thirds of PAs were recurrent and that only recurrent PAs are associated with onset and course of a variety of mental disorders.

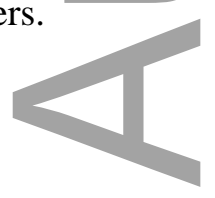

This article is protected by copyright. All rights reserved. 


\section{References}

1. Murray CJ, Vos T, Lozano R, Naghavi M, Flaxman AD, Michaud C, et al. Disability-adjusted life years (DALYs) for 291 diseases and injuries in 21 regions, 1990-2010: a systematic analysis for the Global Burden of Disease Study 2010. Lancet 2012; 380 (9859):2197-223.

2. Whiteford HA, Degenhardt L, Rehm J, Baxter AJ, Ferrari AJ, Erskine HE, et al. Global burden of disease attributable to mental and substance abuse disorders: findings from the Global Burden of Disease Study 2010. Lancet 2013; 382 (9904): 1575-86.

3. Diagnostic and Statistical Manual of Mental Disorders Fifth Edition (DSM-5). American Psychiatric Publishing, 2013. USA: Washington, DC

4. Craske MG, Kircanski K, Epstein A, Wittchen HU, Pine DS, Lewis-Fernández R, Hinton D. Panic disorder: a review of DSM-IV panic disorder and proposals for DSM-V. Depress Anxiety 2010;27(2): 93-112.

5. Klerman GL, Weissman MM, Ouellette R, Johnson J, Greenwald S. Panic attacks in the community: social morbidity and health care utilization. JAMA1991; 265: 742-746.

6. Roy-Byrne PP, Stang P, Wittchen HU, Ustun B, Walters EE, Kessler RC. Lifetime panicdepression comorbidity in the National Comorbidity Survey. Br J Psych 2000; 176: 229-235.

7. Kessler RC, Chiu WT, Jin R, Ruscio AM, Shear K, Walters EE. The epidemiology of panic attacks, panic disorder, and agoraphobia in the National Comorbidity Survey Replication. Arch Gen Psych 2006; 63: 415-424.

8. Eaton WW, Anthony JC, Romanoski A, Tien A, Gallo J, Cai G, Neufeld K, Schlaepfer T, Laugharne J, Chen LS. Onset and recovery from panic disorder in the Baltimore Epidemiologic Catchment Area follow-up. Br J Psychiatry 1998;173:501-7.

9.Eaton WW, Kessler RC, Wittchen HU, Magee WJ. Panic and panic disorder in the United States. Am J Psychiatry. 1994 Mar;151(3):413-20.

10.Marques L1, Robinaugh DJ, LeBlanc NJ, Hinton D. Cross-cultural variations in the prevalence and presentation of anxiety disorders. Expert Rev Neurother. 2011 Feb;11(2):313-22.

11.Weissman MM, Bland RC, Canino GJ, Faravilla C, Greenwald S, Hwu HG, et al. The crossnational Epidemiology of Panic Disorder. Arch Gen Psych 1997; 54: 305-309. 
12. Goodwin RD, Hamilton SP. Panic attack as a marker of core psychopathological processes. Psychopathology 2001; 34(6): 278-88.

13. Kessler RC, Ustün TB. The World Mental Health (WMH) Survey Initiative Version of the World Health Organization (WHO) Composite International Diagnostic Interview (CIDI). Int J Methods Psychiatr Res. 2004;13(2):93-121.

14.The World Bank. Data and Statistics. Accessed May 12, 2009 at: http://go.worldbank.org/D7SNOB8YU0

15. Pennell B, Mneimneh Z, Bowers A, Chardoul S, Wells J, Viana M, Dinkelmann K, Gebler N, Floreseu S, He Y, Huang Y, Tomov T, Vilagut G (2008). Implementation of the World Mental Health Surveys. In The WHO World Mental Health Surveys: Global Perspectives on the Epidemiology of Mental Disorders (ed. R Kessler and T Üstün), pp. 33-57. Cambridge University Press: Cambridge, UK.

16. First MB, Spitzer RL, Gibbon M, Williams JBW. Structured Clinical Interview for DSM-IV Axis I Disorders, Research Version, Non-patient Edition (SCID-I/NP) New York: Biometrics Research, New York State Psychiatric Institute, 2002.

17. Haro JM, Arbabzadeh-Bouchez S, Brugha TS, de Girolamo G, Guyer ME, Jin R, Lepine JP, Mazzi F, Reneses B, Vilagut G, Sampson NA, Kessler RC. Concordance of the Composite International Diagnostic Interview Version 3.0 (CIDI 3.0) with standardized clinical assessments in the WHO World Mental Health surveys. Int J Methods Psychiatr Res. 2006;15(4):167-80.

18. Diagnostic and Statistical Manual of Mental Disorders Fourth Edition (DSM-IV). American Psychiatric Publishing, 2000. USA: Washington, DC.

19. Levinson D, Lakoma MD, Petukhova M, Schoenbaum M, Zaslavsky AM, Angermeyer M, et al. Associations of serious mental illness with earnings: results from the WHO World Mental Health surveys. Br J Psychiatry 2010;197(2):114-21.

20. Wolter, K.M. Introduction to Variance Estimation. New York: Springer-Verlag.,1985 .

21. Research Triangle Institute. SUDAAN: Professional Software for Survey Data Analysis. Research Triangle Park: Research Triangle Institute; 2002. 
22. Kessler RC, Stang PE, Wittchen HU, Ustun TB, Roy-Byrne PP, Walters EE. Lifetime Panicdepression Comorbidity in the National Comorbidity Survey. Arch Gen Psych 1998; 55: 801808.

23. Chen YW, Dilsaver SC. Comorbidity Of Panic Disorder In Bipolar Illness - Evidence From The Epidemiologic Catchment-Area Survey. Am J Psych 1995; 152 (2): 280-282.

24. Bruce SE, Yonkers KA, Otto MW, Eisen JL, Weisberg RB, Pagano M, Shea MT, Keller MB. Influence of Psychiatric Comorbidity on Recovery and recurrence in Generalized Anxiety Disorder, Social Phobia, and Panic Disorder: a 12-Year Prospective Study. Am J Psych 2005; 162: $1179-1187$.

25. Batelaan N, De Graaf R, Van Balkom A, Vollebergh W, Beekman A. Thresholds for health and thresholds for illness: panic disorder versus subthreshold panic disorder. Psychol Med 2007; 37(2): 247-56.

26. Batelaan NM, Rhebergen D, de Graaf R, Spijker J, Beekman AT, Penninx BW. Panic attacks as a dimension of psychopathology: evidence for associations with onset and course of mental disorders and level of functioning. J Clin Psychiatry 2012; 73(9): 1195-202.

27. Knauper B, Cannell CF, Schwarz N, Bruce ML, Kessler RC. Improving the accuracy of major depression age of onset reports in the US National Comorbidity Survey. Int J Methods Psychiatr Res 1999; 8: 39-48.

28. Moffitt TE, Caspi A, Taylor A, Kokaua J, Milne BJ, Polanczyk G, Poulton R. $\underline{\text { How common are }}$ common mental disorders? Evidence that lifetime prevalence rates are doubled by prospective versus retrospective ascertainment. Psychol Med. 2010 Jun;40(6):899-909.

29. Roberson-Nay R, Kendler KS. Panic disorder and its subtypes: a comprehensive analysis of panic symptom heterogeneity using epidemiological and treatment seeking samples. Psychol Med 2011; 41: 2411-2421.

30. Goodwin RD, Faravelli C, Rosi S, Cosci F, Truglia E, de Graaf R, Wittchen HU. The epidemiology of panic disorder and agoraphobia in Europe. Eur Neuropsychopharmacol. 2005 Aug;15(4):435-43. 
Table 1. World Mental Health sample characteristics by World Bank Income categoriesa.

\begin{tabular}{|c|c|c|c|c|c|c|c|}
\hline \multirow[b]{2}{*}{ Country } & \multirow[b]{2}{*}{ Survey $^{\mathbf{b}}$} & \multirow[b]{2}{*}{ Sample characteristics ${ }^{c}$} & \multirow[b]{2}{*}{$\begin{array}{l}\text { Field } \\
\text { dates }\end{array}$} & \multirow[b]{2}{*}{$\begin{array}{l}\text { Age } \\
\text { range }^{d}\end{array}$} & \multicolumn{2}{|c|}{ Sample Size } & \multirow[b]{2}{*}{$\begin{array}{l}\text { Response } \\
\text { rate }(\%)^{\mathrm{e}}\end{array}$} \\
\hline & & & & & Part 1 & $\begin{array}{c}\text { Part } 2 \\
\text { sub- } \\
\text { sample }\end{array}$ & \\
\hline \multicolumn{8}{|c|}{ Low - lower middle income countries } \\
\hline Colombia & NSMH & $\begin{array}{l}\text { All urban areas of the country (approximately } 73 \% \\
\text { of the total national population) }\end{array}$ & 2003 & $18-65$ & 4426 & 2381 & 87,7 \\
\hline Iraq & IMHS & Nationally representative. & $2006-7$ & $18+$ & 4332 & 4332 & 95,2 \\
\hline Nigeria & NSMHW & $\begin{array}{l}21 \text { of the } 36 \text { states in the country, representing } \\
57 \% \text { of the national population. The surveys were } \\
\text { conducted in Yoruba, Igbo, Hausa and Efik } \\
\text { languages. }\end{array}$ & $2002-3$ & $18+$ & 6752 & 2143 & 79,3 \\
\hline Peru & EMSMP & Nationally representative. & $2004-5$ & $18-65$ & 3930 & 1801 & 90,2 \\
\hline PRC $^{f}$ Beijing/Shanghai & B-WMH S-WMH & Beijing and Shanghai metropolitan areas. & $2002-3$ & $18+$ & 5201 & 1628 & 74,7 \\
\hline PRC Shen Zhen & Shenzhen & $\begin{array}{l}\text { Shenzhen metropolitan area. Included temporary } \\
\text { residents as well as household residents. }\end{array}$ & $2006-7$ & $18+$ & 7132 & 2475 & 80,0 \\
\hline Ukraine & CMDPSD & Nationally representative. & 2002 & $18+$ & 4725 & 1719 & 78,3 \\
\hline
\end{tabular}

This is the author manuscript accepted for publication and has undergone full peer review but has not been through the copyediting, typesetting, pagination and proofreading process, which may lead to differences between this version and the Version of Record. Please cite this article as doi: 10.1002/da.22572.

This article is protected by copyright. All rights reserved. 


\begin{tabular}{|l} 
Total \\
Upper-middle income count \\
Brazil \\
Bulgaria \\
Colombia (Medellin)s \\
Lebanon \\
Mexico \\
Romania \\
Total \\
High-income countries \\
Australia \\
Belgium \\
France \\
Germany \\
Israel \\
Italy \\
Japan \\
New Zealand
\end{tabular}

São Paulo Megacity
NSHS
MMHHS
LEBANON
M-NCS
RMHS

São Paulo metropolitan area.

Nationally representative.

Medellin metropolitan area

Nationally representative.

All urban areas of the country (approximately 75\%

of the total national population).

Nationally representative.

\begin{tabular}{|c|c|c|c|c|}
\hline & & 32568 & 14679 & 81,4 \\
\hline $2005-7$ & $18+$ & 5037 & 2942 & 81,3 \\
\hline 2003-7 & $18+$ & 5318 & 2233 & 72,0 \\
\hline 2011-2 & $18-65$ & 3261 & 1673 & 97,2 \\
\hline $2002-3$ & $18+$ & 2857 & 1031 & 70,0 \\
\hline 2001-2 & $18-65$ & 5782 & 2362 & 76,6 \\
\hline \multirow[t]{2}{*}{$2005-6$} & $18+$ & 2357 & 2357 & 70,9 \\
\hline & & 24612 & 12598 & 77,2 \\
\hline 2007 & $18+$ & 8463 & 8463 & 60,0 \\
\hline 2001-2 & $18+$ & 2419 & 1043 & 50,6 \\
\hline $2001-2$ & $18+$ & 2894 & 1436 & 45,9 \\
\hline $2002-3$ & $18+$ & 3555 & 1323 & 57,8 \\
\hline $2002-4$ & $21+$ & 4859 & 4859 & 72,6 \\
\hline $2001-2$ & $18+$ & 4712 & 1779 & 71,3 \\
\hline $2002-6$ & $20+$ & 4129 & 1682 & 55,1 \\
\hline 2003-4 & $18+$ & 12790 & 7312 & 73,3 \\
\hline
\end{tabular}

This article is protected by copyright. All rights reserved.

Nationally representative.

Nationally representative.

Nationally representative.

Nationally representative.

Nationally representative.

Nationally representative.

Eleven metropolitan areas.

Nationally representative. 


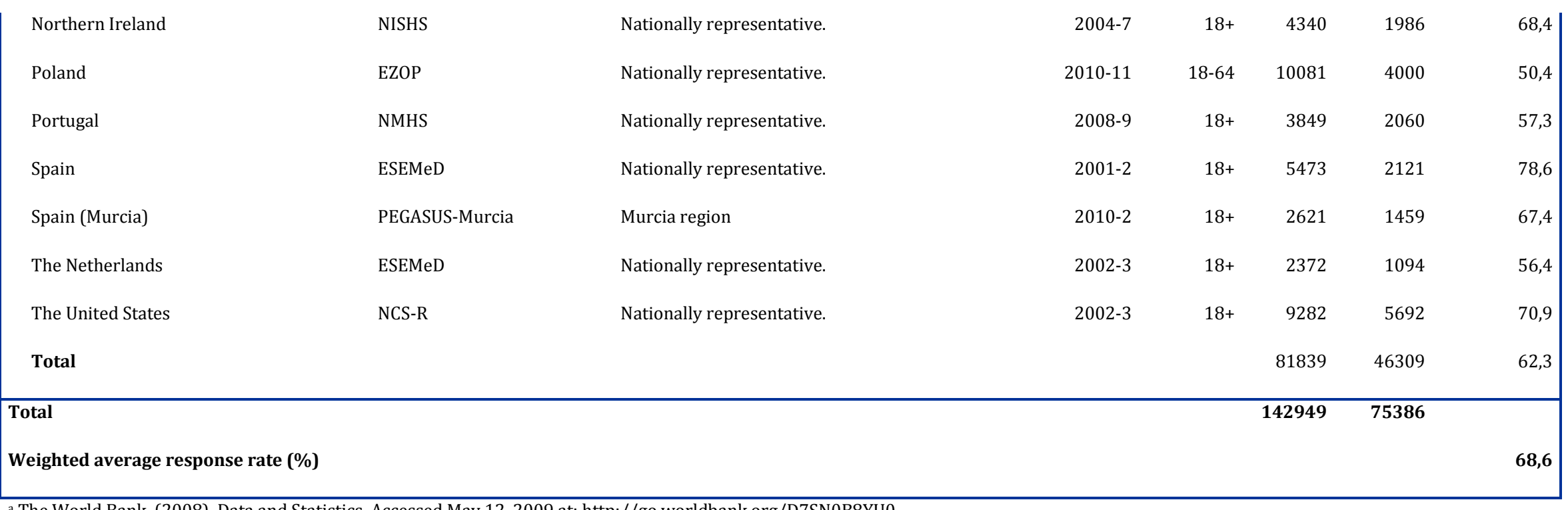

a The World Bank. (2008). Data and Statistics. Accessed May 12, 2009 at: http://go.worldbank.org/D7SN0B8YU0

b NSMH (The Colombian National Study of Mental Health); IMHS (Iraq Mental Health Survey); NSMHW (The Nigerian Survey of Mental Health and Wellbeing); EMSMP (La Encuesta Mundial de Salud Mental en el Peru); B-WMH (The Beijing World Mental Health Survey); S-WMH (The Shanghai World Mental Health Survey); CMDPSD (Comorbid Mental Disorders during Periods of Social Disruption); NSHS (Bulgaria National Survey of Health and Stress); MMHHS (Medellín Mental Health Household Study); LEBANON (Lebanese Evaluation of the Burden of Ailments and Needs of the Nation); M-NCS (The Mexico National Comorbidity Survey); RMHS (Romania Mental Health Survey); NSMHWB (National Survey of Mental Health and Wellbeing); ESEMeD (The European Study Of The Epidemiology Of Mental Disorders); NHS (Israel National Health Survey); WMHJ2002-2006 (World Mental Health Japan Survey); NZMHS (New Zealand Mental Health Survey); NISHS

(Northern Ireland Study of Health and Stress); EZOP (Epidemiology of Mental Disorders and Access to Care Survey); NMHS (Portugal National Mental Health Survey); PEGASUS-Murcia (Psychiatric Enquiry to General Population in Southeast Spain-Murcia);NCS-R (The US National Comorbidity Survey Replication).

cMost WMH surveys are based on stratified multistage clustered area probability household samples in which samples of areas equivalent to counties or municipalities in the US were selected in the first stage followed by one or more subsequent stages of geographic sampling (e.g., towns within counties, blocks within towns, households within blocks) to arrive at a sample of households in each of which a listing of household members was created and one or two people were selected from this listing to be interviewed. No substitution was allowed when the originally sampled household resident could not be interviewed. These household samples were selected from Census area data in all countries other than France (where telephone directories were used to select households) and the Netherlands (where postal registries were used to select households). Several WMH surveys (Belgium, Germany, Italy) used municipal resident registries to select respondents without listing households. The Japanese sample is the only totally un-clustered sample, with households randomly selected in each of the 11 metropolitan areas and one random respondent selected in each sample household. 19 of the 28 surveys are based on nationally representative household samples.

This article is protected by copyright. All rights reserved. 
dFor the purposes of cross-national comparisons we limit the sample to those $18+$.

eThe response rate is calculated as the ratio of the number of households in which an interview was completed to the number of households originally sampled, excluding from the denominator households known not to be eligible either because of being vacant at the time of initial contact or because the residents were unable to speak the designated languages of the survey. The weighted average response rate is $68,6 \%$.

fPeople’s Republic of China

gThe newer Colombian survey in Medellin was classified as upper-middle income country (due to a change of classification by The World Bank) although the original survey Colombia was classified as a low-lower middle income country.

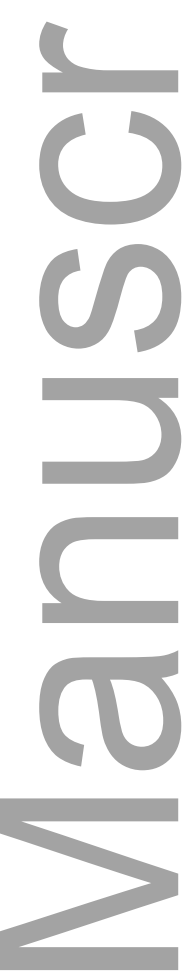

This article is protected by copyright. All rights reserved. 
Table 2. Lifetime prevalence of panic attack (PA) and panic disorder (PD) in the World Mental Health Surveys.

\begin{tabular}{|c|c|c|c|c|c|c|c|c|c|c|c|c|}
\hline \multirow{3}{*}{ Country } & \multicolumn{6}{|c|}{ Among total population } & \multicolumn{4}{|c|}{$\begin{array}{l}\text { Among lifetime PA without } \\
\text { lifetime PD cases }\end{array}$} & \multirow{3}{*}{$\begin{array}{c}\text { Part } 1 \\
\text { sample } \\
\text { sizes }\end{array}$} & \multirow{3}{*}{$\begin{array}{c}\text { Sample } \\
\text { size } \\
\text { used }^{b}\end{array}$} \\
\hline & \multicolumn{2}{|c|}{ Lifetime PA } & \multicolumn{2}{|c|}{$\begin{array}{c}\text { Lifetime PA } \\
\text { without } \\
\text { lifetime PD } \\
\text { cases }\end{array}$} & \multicolumn{2}{|c|}{ Lifetime PD } & \multicolumn{2}{|c|}{$\begin{array}{l}\text { proportion of } \\
\text { single attack }\end{array}$} & \multicolumn{2}{|c|}{$\begin{array}{c}\text { proportion } \\
\text { of recurrent } \\
\text { attacksa }^{\mathbf{a}}\end{array}$} & & \\
\hline & $\%$ & SE & $\%$ & SE & $\%$ & SE & $\%$ & SE & $\%$ & SE & & \\
\hline Low-Lower middle income countries & 6,9 & 0,2 & 6,1 & 0,2 & 0,8 & 0,1 & 29,8 & 1,4 & 61,5 & 1,4 & 36498 & 36395 \\
\hline Colombia & 18,5 & 0,7 & 17,2 & 0,8 & 1,3 & 0,2 & 43,4 & 2,6 & 52,8 & 2,5 & 4426 & 4422 \\
\hline Iraq & 7,5 & 0,6 & 6,2 & 0,6 & 1,4 & 0,3 & 27,6 & 4,8 & 47,4 & 5,5 & 4332 & 4295 \\
\hline Nigeria & 2,6 & 0,3 & 2,4 & 0,3 & 0,2 & 0,1 & 25,0 & 4,9 & 67,3 & 5,3 & 6752 & 6713 \\
\hline Peru & 7,1 & 0,4 & 6,7 & 0,4 & 0,5 & 0,1 & 31,2 & 2,9 & 62,7 & 2,6 & 3930 & 3929 \\
\hline PRC China & 2,1 & 0,3 & 1,7 & 0,2 & 0,4 & 0,1 & 17,2 & 4,5 & 79,5 & 4,9 & 5201 & 5197 \\
\hline PRC Shen Zhen & 2,5 & 0,3 & 2,2 & 0,3 & 0,3 & 0,1 & 20,9 & 5,0 & 79,1 & 5,0 & 7132 & 7129 \\
\hline Ukraine & 13,4 & 0,6 & 11,2 & 0,6 & 2,2 & 0,3 & 16,8 & 1,7 & 70,4 & 2,0 & 4725 & 4710 \\
\hline Upper-middle income countries & 11,1 & 0,3 & 10,0 & 0,3 & 1,1 & 0,1 & 28,7 & 1,1 & 57,1 & 1,2 & 24612 & 24565 \\
\hline
\end{tabular}

This article is protected by copyright. All rights reserved. 


\begin{tabular}{|c|c|c|c|c|c|c|c|c|c|c|c|c|}
\hline Brazil & 11,7 & 0,6 & 10,0 & 0,6 & 1,7 & 0,2 & 26,1 & 1,7 & 56,8 & 2,2 & 5037 & 5023 \\
\hline Bulgaria & 6,0 & 0,3 & 5,0 & 0,3 & 1,1 & 0,1 & 14,7 & 2,4 & 53,5 & 3,9 & 5318 & 5301 \\
\hline Colombia (Medellin) & 20,1 & 1,3 & 18,8 & 1,2 & 1,3 & 0,3 & 39,5 & 2,4 & 48,7 & 2,5 & 3261 & 3260 \\
\hline Lebanon & 13,9 & 0,9 & 13,4 & 0,9 & 0,5 & 0,1 & 32,2 & 2,9 & 55,9 & 2,6 & 2857 & 2851 \\
\hline Mexico & 7,8 & 0,5 & 6,8 & 0,5 & 1,0 & 0,2 & 28,8 & 3,0 & 69,5 & 2,9 & 5782 & 5781 \\
\hline Romania & 13,9 & 0,8 & 13,3 & 0,8 & 0,7 & 0,2 & 19,2 & 2,9 & 63,1 & 3,2 & 2357 & 2349 \\
\hline High income countries & 16,6 & 0,2 & 14,4 & 0,2 & 2,2 & 0,1 & 22,5 & 0,5 & 69,4 & 0,5 & 81839 & 81754 \\
\hline Australia & 21,5 & 0,6 & 17,9 & 0,6 & 3,7 & 0,3 & 25,6 & 1,5 & 71,9 & 1,7 & 8463 & 8461 \\
\hline Belgium & 10,1 & 1,0 & 8,5 & 0,8 & 1,6 & 0,3 & 27,6 & 3,2 & 58,2 & 3,2 & 2419 & 2417 \\
\hline France & 11,1 & 0,9 & 9,0 & 0,8 & 2,1 & 0,3 & 37,5 & 3,5 & 58,9 & 3,6 & 2894 & 2894 \\
\hline Germany & 10,1 & 0,6 & 8,5 & 0,6 & 1,6 & 0,2 & 29,5 & 3,9 & 66,5 & 3,9 & 3555 & 3555 \\
\hline Israel & 10,0 & 0,5 & 9,1 & 0,5 & 0,9 & 0,1 & 24,3 & 2,2 & 55,6 & 2,5 & 4859 & 4853 \\
\hline Italy & 8,0 & 0,5 & 6,4 & 0,4 & 1,6 & 0,2 & 14,9 & 2,2 & 70,0 & 2,7 & 4712 & 4708 \\
\hline Japan & 6,6 & 0,4 & 5,9 & 0,4 & 0,8 & 0,1 & 28,2 & 3,2 & 65,8 & 3,7 & 4129 & 4126 \\
\hline New Zealand & 27,4 & 0,6 & 24,7 & 0,5 & 2,8 & 0,2 & 22,8 & 1,0 & 74,3 & 1,0 & 12790 & 12781 \\
\hline Northern Ireland & 24,4 & 0,8 & 21,1 & 0,7 & 3,3 & 0,3 & 23,1 & 1,8 & 70,6 & 2,0 & 4340 & 4335 \\
\hline Poland & 5,9 & 0,2 & 5,6 & 0,2 & 0,3 & 0,1 & 11,3 & 1,1 & 47,1 & 2,1 & 10081 & 10049 \\
\hline
\end{tabular}

This article is protected by copyright. All rights reserved. 


\begin{tabular}{|c|c|c|c|c|c|c|c|c|c|c|c|c|}
\hline Portugal & 19,6 & 0,7 & 17,9 & 0,6 & 1,7 & 0,3 & 21,9 & 1,9 & 64,4 & 2,1 & 3849 & 3841 \\
\hline Spain & 9,6 & 0,5 & 8,4 & 0,5 & 1,2 & 0,2 & 33,5 & 3,0 & 54,1 & 3,2 & 5473 & 5472 \\
\hline Spain (Murcia) & 16,3 & 1,0 & 14,7 & 1,0 & 1,6 & 0,4 & 27,1 & 2,3 & 54,5 & 4,1 & 2621 & 2617 \\
\hline The Netherlands & 14,0 & 0,8 & 11,0 & 0,7 & 3,0 & 0,4 & 24,3 & 3,7 & 72,3 & 3,7 & 2372 & 2370 \\
\hline The United States & 27,3 & 0,7 & 22,6 & 0,7 & 4,7 & 0,2 & 16,0 & 0,8 & 79,2 & 0,8 & 9282 & 9275 \\
\hline All countries combined & 13,2 & 0,1 & 11,5 & 0,1 & 1,7 & $\mathbf{0 , 0}$ & 24,4 & 0,4 & 66,5 & 0,5 & 147264 & 142714 \\
\hline WHO regions ${ }^{c}$ & & & & & & & & & & & & \\
\hline Region of the Americas & 16,8 & 0,4 & 14,6 & 0,4 & 2,2 & 0,1 & 26,7 & 0,9 & 66,6 & 0,9 & 31718 & 31690 \\
\hline Western Pacific Region & 15,6 & 0,3 & 13,7 & 0,2 & 2,0 & 0,1 & 23,7 & 0,8 & 73,4 & 0,8 & 37715 & 37694 \\
\hline Eastern Mediterranean Region & 10,0 & 0,4 & 9,1 & 0,4 & 1,0 & 0,1 & 27,9 & 1,8 & 53,7 & 1,9 & 12048 & 11999 \\
\hline Western European Region & 13,6 & 0,2 & 11,7 & 0,2 & 1,9 & 0,1 & 25,7 & 0,9 & 64,1 & 1,0 & 32235 & 32209 \\
\hline Eastern European Region & 8,4 & 0,2 & 7,4 & 0,2 & 0,9 & 0,1 & 15,0 & 0,9 & 58,4 & 1,3 & 22481 & 22409 \\
\hline Comparison between countries & \multicolumn{2}{|c|}{$\begin{array}{c}\chi^{2} 27=164.6^{*} \\
P<.001\end{array}$} & \multicolumn{2}{|c|}{$\begin{array}{c}\chi^{2} 27=143.0^{*} \\
P<.001\end{array}$} & \multicolumn{2}{|c|}{$\begin{array}{c}\chi^{2} 27=32.4^{*} \\
P<.001\end{array}$} & \multicolumn{2}{|c|}{$\begin{array}{c}\chi^{2} 27=12.7^{*} \\
P<.001\end{array}$} & \multicolumn{2}{|c|}{$\begin{array}{c}\chi^{2} 27=16.9 * \\
P<.001\end{array}$} & & \\
\hline
\end{tabular}

This article is protected by copyright. All rights reserved. 
Comparison between low, middle and

high income country groups ${ }^{d}$

$$
\chi^{2}=638.7 \text {, }
$$

$\mathbf{P}<.001$ $\chi^{2}=529.7^{*}$

$\mathbf{P}<.001$ $\chi^{2}=130.8^{*}$

$\mathbf{P}<.001$

$$
\chi^{2}=22.5^{*}
$$

$\mathbf{P}<.001$

$\chi^{2}{ }_{2}=50.5^{*}$,

$\mathrm{P}<.001$

$$
\begin{aligned}
& \chi^{2}{ }_{5}=320.6^{*}, \quad \chi^{2_{5}}=275.2^{*}, \quad \chi^{2_{5}}=85.8^{*}, \quad \chi^{2}=20.3^{*}, \quad \chi^{2}=30.8^{*}, \\
& P<.001 \quad P<.001 \quad P<.001 \quad P<.001 \quad P<.001
\end{aligned}
$$

aRecurrent panic attacks is more than one panic attack. Percentages do not count up to $100 \%$ as $9.1 \%$ of those with PAs did not recall how may PAs they had.

bSample size used after excluding lifetime panic attack cases with missing age of onset.

Region of the Americas (Colombia, Mexico, Brazil, Peru, The United States, Medellin); African region (Nigeria); Western Pacific region (PRC Shen Zhen, PRC Beijing and Shanghai, Japan, Australia,New Zealand); Eastern Mediterranean region (Israel, Iraq, Lebanon); Western European region (Belgium, France, Germany, Italy, The Netherlands, Spain, Northern Ireland, Portugal, Murcia); Eastern European region (Romania, Bulgaria, Poland, Ukraine)

dChi-square test of homogeneity to determine if there is variation in prevalence estimates across countries.

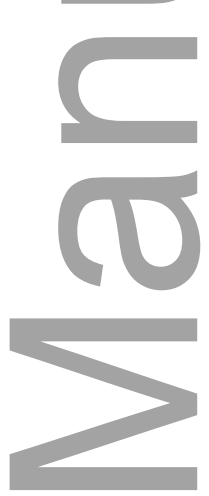

This article is protected by copyright. All rights reserved. 
Table 3. Comorbidity of single and recurrent panic attacks in the absence of panic disorder with mental disorders.

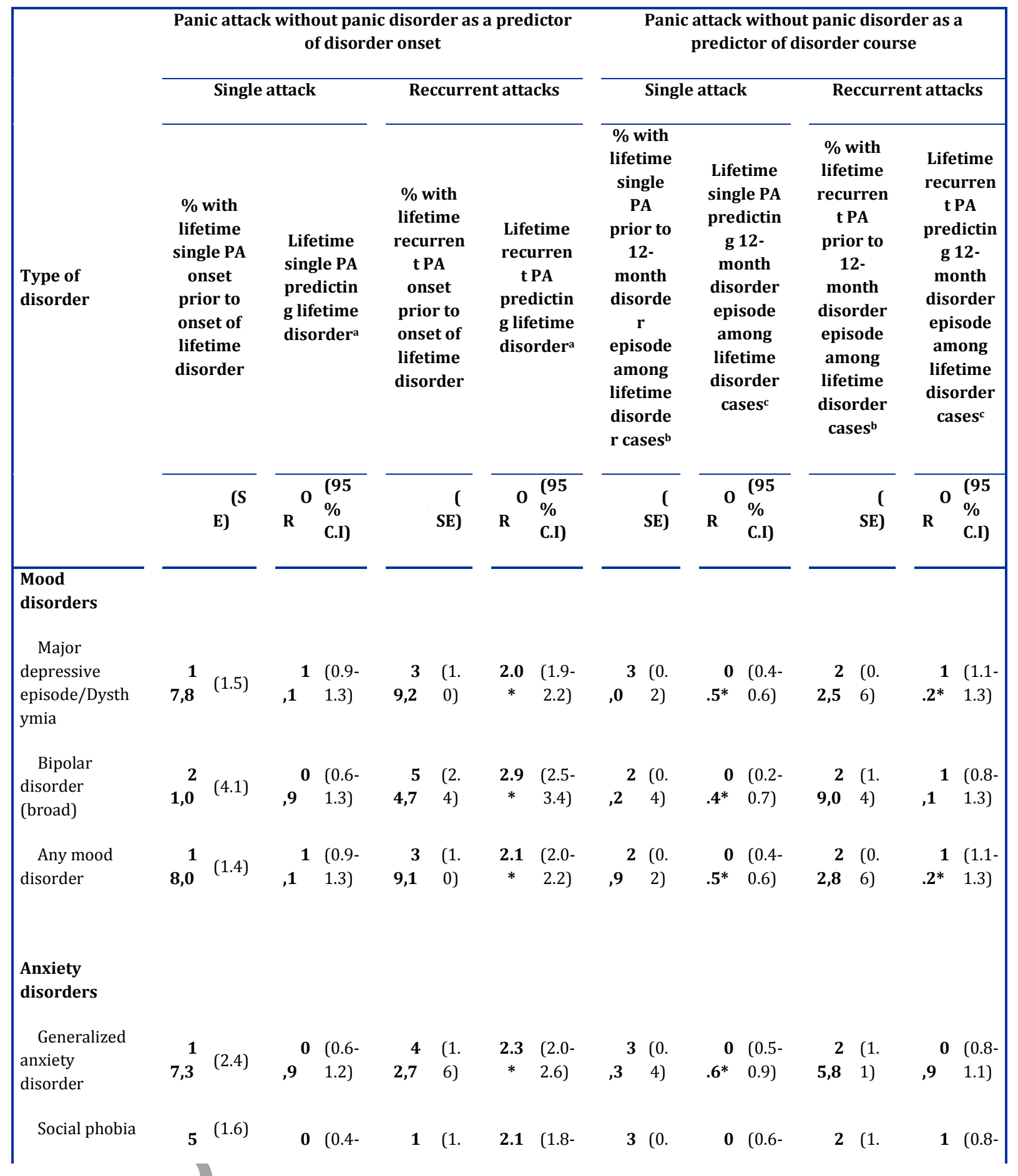

This is the author manuscript accepted for publication and has undergone full peer review but has not been through the copyediting, typesetting, pagination and proofreading process, which may lead to differences between this version and the Version of Record. Please cite this article as doi:

10.1002/da.22572.

This article is protected by copyright. All rights reserved. 


\begin{tabular}{|c|c|c|c|c|c|c|c|c|c|c|c|c|c|c|c|c|}
\hline & ,9 & & 6 & 1.1) & 9,5 & 3) & $*$ & 2.4) &, 4 & 4) & ,9 & 1.2) & 7,9 & 0 ) & ,0 & 1.1) \\
\hline $\begin{array}{l}\text { Specific } \\
\text { phobia }\end{array}$ &, $9^{1}$ & $(0.7)$ & $\begin{array}{c}0 \\
.5^{*}\end{array}$ & $\begin{array}{l}(0.2- \\
1.0)\end{array}$ & $5^{7}$ & $\begin{array}{l}(0 . \\
7)\end{array}$ & $\begin{array}{c}1.3 \\
*\end{array}$ & $\begin{array}{l}(1.1- \\
1.6)\end{array}$ &, $5^{3}$ & $\begin{array}{l}(0 . \\
3)\end{array}$ &, 9 & $\begin{array}{l}(0.7- \\
1.2)\end{array}$ & $\begin{array}{r}2 \\
1,5\end{array}$ & $\begin{array}{l}(0 . \\
6)\end{array}$ & $\mathbf{0}^{1}$ & $\begin{array}{l}(0.8- \\
1.1)\end{array}$ \\
\hline $\begin{array}{l}\text { Agoraphobia } \\
\text { without panic }\end{array}$ & $9^{9}$ & $(5.6)$ &, $8^{0}$ & $\begin{array}{l}(0.3- \\
2.7)\end{array}$ & $\begin{array}{r}2 \\
5,3\end{array}$ & $\begin{array}{l}(2 . \\
3)\end{array}$ & $\begin{array}{c}2.9 \\
*\end{array}$ & $\begin{array}{l}(2.3- \\
3.7)\end{array}$ &, $2^{4}$ & $\begin{array}{l}(1 . \\
0)\end{array}$ &, $0^{1}$ & $\begin{array}{l}(0.4- \\
2.4)\end{array}$ & $\begin{array}{r}3 \\
7,1\end{array}$ & $\begin{array}{l}(2 . \\
3)\end{array}$ &, $2^{1}$ & $\begin{array}{l}(0.8- \\
1.6)\end{array}$ \\
\hline $\begin{array}{l}\text { Post- } \\
\text { traumatic } \\
\text { stress disorder }\end{array}$ & $\begin{array}{r}1 \\
2,0\end{array}$ & $(2.3)$ &, $7^{0}$ & $\begin{array}{l}(0.5- \\
1.0)\end{array}$ & $\begin{array}{r}4 \\
1,0\end{array}$ & $\begin{array}{l}(1 . \\
8)\end{array}$ & $\begin{array}{c}2.4 \\
*\end{array}$ & $\begin{array}{l}(2.1- \\
2.7)\end{array}$ & $\mathbf{0}^{4}$ & $\begin{array}{l}(0 . \\
6)\end{array}$ & $\begin{array}{c}0 \\
.6^{*}\end{array}$ & $\begin{array}{l}(0.4- \\
1.0)\end{array}$ & $\begin{array}{r}3 \\
1,0\end{array}$ & $\begin{array}{l}(1 . \\
4)\end{array}$ &, $2^{1}$ & $\begin{array}{l}(0.9- \\
1.4)\end{array}$ \\
\hline $\begin{array}{l}\text { Any anxiety } \\
\text { disorder }\end{array}$ & $1^{6}$ & $(1.0)$ & $\begin{array}{c}0 \\
.7 *\end{array}$ & $\begin{array}{l}(0.5- \\
1.0)\end{array}$ & $\begin{array}{r}1 \\
8,1\end{array}$ & $\begin{array}{l}(0 . \\
8)\end{array}$ & $\begin{array}{c}1.9 \\
*\end{array}$ & $\begin{array}{l}(1.7- \\
2.1)\end{array}$ & $5^{3}$ & $\begin{array}{l}(0 . \\
2)\end{array}$ & $\begin{array}{c}0 \\
.7^{*}\end{array}$ & $\begin{array}{l}(0.5- \\
0.9)\end{array}$ & $\begin{array}{r}2 \\
4,2\end{array}$ & $\begin{array}{l}(0 . \\
6)\end{array}$ & $\mathbf{0}^{1}$ & $\begin{array}{l}(0.9- \\
1.2)\end{array}$ \\
\hline $\begin{array}{l}\text { Impulse- } \\
\text { control } \\
\text { disorders }\end{array}$ & & & & & & & & & & & & & & & & \\
\hline $\begin{array}{l}\text { Intermittent } \\
\text { explosive } \\
\text { disorder }\end{array}$ & $\begin{array}{r}1 \\
5,6\end{array}$ & $(3.0)$ &, $3^{1}$ & $\begin{array}{l}(0.9- \\
1.9)\end{array}$ & $\begin{array}{r}3 \\
6,9\end{array}$ & $\begin{array}{l}(2 . \\
1)\end{array}$ & $\begin{array}{c}2.7 \\
*\end{array}$ & $\begin{array}{l}(2.3- \\
3.2)\end{array}$ &, $7^{2}$ & $\begin{array}{l}(0 . \\
5)\end{array}$ &, $8^{0}$ & $\begin{array}{l}(0.5- \\
1.4)\end{array}$ & $\begin{array}{r}2 \\
0,9\end{array}$ & $\begin{array}{l}(1 . \\
2)\end{array}$ & $\mathbf{1}^{1}$ & $\begin{array}{l}(0.8- \\
1.4)\end{array}$ \\
\hline $\begin{array}{l}\text { Binge eating } \\
\text { disorder }\end{array}$ & $\begin{array}{r}3 \\
5,1\end{array}$ & $(9.4)$ &,$^{1}$ & $\begin{array}{l}(0.7- \\
3.1)\end{array}$ & $\begin{array}{r}6 \\
2,8\end{array}$ & $\begin{array}{l}(4 . \\
2)\end{array}$ & $\begin{array}{c}2.8 \\
*\end{array}$ & $\begin{array}{l}(2.1- \\
3.6)\end{array}$ &, $8^{3}$ & $\begin{array}{l}(1 . \\
1)\end{array}$ &, $2^{1}$ & $\begin{array}{l}(0.4- \\
3.4)\end{array}$ & $\begin{array}{r}2 \\
4,1\end{array}$ & $\begin{array}{l}(2 . \\
7)\end{array}$ &, 9 & $\begin{array}{l}(0.6- \\
1.4)\end{array}$ \\
\hline $\begin{array}{l}\text { Bulimia } \\
\text { nervosa }\end{array}$ & $\begin{array}{r}2 \\
8,7\end{array}$ & $\begin{array}{c}(10 . \\
6)\end{array}$ &, $5^{1}$ & $\begin{array}{l}(0.6- \\
3.6)\end{array}$ & $\begin{array}{r}5 \\
0,0\end{array}$ & $\begin{array}{l}(5 . \\
0)\end{array}$ & $\begin{array}{c}2.4 \\
*\end{array}$ & $\begin{array}{l}(1.7- \\
3.5)\end{array}$ &, $0^{6}$ & $\begin{array}{l}(2 . \\
2)\end{array}$ &, $3^{2}$ & $\begin{array}{l}(0.9- \\
6.1)\end{array}$ & $\begin{array}{r}2 \\
4,8\end{array}$ & $\begin{array}{l}(4 . \\
4)\end{array}$ &, $0^{1}$ & $\begin{array}{l}(0.6- \\
1.8)\end{array}$ \\
\hline $\begin{array}{l}\text { Any impulse- } \\
\text { control } \\
\text { disorder }\end{array}$ & $\begin{array}{r}2 \\
3,1\end{array}$ & (3.9) & $\begin{array}{c}1 \\
.5^{*}\end{array}$ & $\begin{array}{l}(1.0- \\
2.2)\end{array}$ & $\begin{array}{r}4 \\
1,5\end{array}$ & $\begin{array}{l}(2 . \\
1)\end{array}$ & $\begin{array}{c}2.5 \\
*\end{array}$ & $\begin{array}{l}(2.1- \\
2.9)\end{array}$ & $2^{3}$ & $\begin{array}{l}(0 . \\
5)\end{array}$ &, $0^{1}$ & $\begin{array}{l}(0.6- \\
1.6)\end{array}$ & $\begin{array}{r}2 \\
2,2\end{array}$ & $\begin{array}{l}(1 . \\
2)\end{array}$ & $\mathbf{0}^{1}$ & $\begin{array}{l}(0.8- \\
1.3)\end{array}$ \\
\hline $\begin{array}{l}\text { Substance-use } \\
\text { disorders }\end{array}$ & & & & & & & & & & & & & & & & \\
\hline $\begin{array}{l}\text { Alcohol } \\
\text { abuse }\end{array}$ & $\begin{array}{r}2 \\
5,1\end{array}$ & $(2.8)$ & $\begin{array}{c}1 \\
.3^{*}\end{array}$ & $\begin{array}{l}(1.0- \\
1.8)\end{array}$ & $\begin{array}{r}5 \\
5,6\end{array}$ & $\begin{array}{l}(1 . \\
6)\end{array}$ & $\begin{array}{c}2.3 \\
*\end{array}$ & $\begin{array}{l}(2.1- \\
2.6)\end{array}$ & $2^{3}$ & $\begin{array}{l}(0 . \\
6)\end{array}$ &, $0^{1}$ & $\begin{array}{l}(0.7- \\
1.5)\end{array}$ & $\begin{array}{r}1 \\
6,6\end{array}$ & $\begin{array}{l}(1 . \\
1)\end{array}$ &, 1 & $\begin{array}{l}(0.9- \\
1.3)\end{array}$ \\
\hline $\begin{array}{c}\text { Alcohol } \\
\text { dependence }\end{array}$ & $\begin{array}{r}2 \\
0,0\end{array}$ & (4.3) & $9^{0}$ & $\begin{array}{l}(0.6- \\
1.4)\end{array}$ & $\begin{array}{r}5 \\
6,9\end{array}$ & $\begin{array}{l}(2 . \\
4)\end{array}$ & $\begin{array}{c}2.7 \\
*\end{array}$ & $\begin{array}{l}(2.3- \\
3.2)\end{array}$ & $0^{3}$ & $\begin{array}{l}(1 . \\
0)\end{array}$ &, $7^{0}$ & $\begin{array}{l}(0.3- \\
1.7)\end{array}$ & $\begin{array}{r}2 \\
1,0\end{array}$ & $\begin{array}{l}(2 . \\
0)\end{array}$ & $\mathbf{0}^{1}$ & $\begin{array}{l}(0.8- \\
1.3)\end{array}$ \\
\hline Drug abuse & $\begin{array}{r}2 \\
2,9\end{array}$ & $(4.0)$ & $3^{1}$ & $\begin{array}{l}(0.9- \\
1.9)\end{array}$ & $\begin{array}{r}5 \\
3,1\end{array}$ & $\begin{array}{l}(2 . \\
4)\end{array}$ & $\begin{array}{c}2.6 \\
*\end{array}$ & $\begin{array}{l}(2.2- \\
3.0)\end{array}$ & $3^{3}$ & $\begin{array}{l}(1 . \\
0)\end{array}$ & $6^{0}$ & $\begin{array}{l}(0.3- \\
1.1)\end{array}$ & $\begin{array}{r}2 \\
5,6\end{array}$ & $\begin{array}{l}(2 . \\
5)\end{array}$ & $2^{1}$ & $\begin{array}{l}(0.9- \\
1.7)\end{array}$ \\
\hline $\begin{array}{c}\text { Drug } \\
\text { dependence }\end{array}$ & $\begin{array}{r}2 \\
3,8\end{array}$ & (6.3) &, 1 & $\begin{array}{l}(0.6- \\
2.1)\end{array}$ & $\begin{array}{r}5 \\
7,0\end{array}$ & $\begin{array}{l}(3 . \\
3)\end{array}$ & $\begin{array}{c}3.0 \\
*\end{array}$ & $\begin{array}{l}(2.4- \\
3.8)\end{array}$ & $3^{3}$ & $\begin{array}{l}(1 . \\
3)\end{array}$ &, $5^{0}$ & $\begin{array}{l}(0.2- \\
1.3)\end{array}$ & $\begin{array}{r}3 \\
5,8\end{array}$ & $\begin{array}{l}(4 . \\
3)\end{array}$ & $\begin{array}{c}1 \\
.8^{*}\end{array}$ & $\begin{array}{l}(1.1- \\
2.8)\end{array}$ \\
\hline $\begin{array}{l}\text { Any } \\
\text { substance-use } \\
\text { disorder }\end{array}$ & $\begin{array}{r}2 \\
0,8\end{array}$ & $(2.4)$ & $2^{1}$ & $\begin{array}{l}(0.9- \\
1.6)\end{array}$ & $\begin{array}{r}5 \\
1,1\end{array}$ & $\begin{array}{l}(1 . \\
5)\end{array}$ & $\begin{array}{c}2.3 \\
*\end{array}$ & $\begin{array}{l}(2.0- \\
2.5)\end{array}$ &, $4^{3}$ & $\begin{array}{l}(0 . \\
6)\end{array}$ &, $0^{1}$ & $\begin{array}{l}(0.6- \\
1.6)\end{array}$ & $\begin{array}{r}1 \\
8,3\end{array}$ & $\begin{array}{l}(1 . \\
0)\end{array}$ &, $2^{1}$ & $\begin{array}{l}(1.0- \\
1.4)\end{array}$ \\
\hline $\begin{array}{l}\text { Any mental } \\
\text { disorder }\end{array}$ & $\begin{array}{r}1 \\
0,9\end{array}$ & $(0.9)$ &, 1 & $\begin{array}{l}(0.9- \\
1.3)\end{array}$ & $\begin{array}{r}2 \\
3,3\end{array}$ & $\begin{array}{l}(0 . \\
7)\end{array}$ & $\begin{array}{c}2.0 \\
*\end{array}$ & $\begin{array}{l}(1.8- \\
2.2)\end{array}$ &, $4^{3}$ & $\begin{array}{l}(0 . \\
2)\end{array}$ & $\begin{array}{r}0 \\
.7^{*}\end{array}$ & $\begin{array}{l}(0.6- \\
0.8)\end{array}$ & $\begin{array}{r}2 \\
1,2\end{array}$ & $\begin{array}{l}(0 . \\
4)\end{array}$ & $\begin{array}{c}1 \\
.3^{*}\end{array}$ & $\begin{array}{l}(1.2- \\
1.4)\end{array}$ \\
\hline
\end{tabular}

This article is protected by copyright. All rights reserved. 
*Significant at

the .05 level, 2

sided test.

aEach model was estimated using lifetime panic attack as predictor of lifetime comorbid disorder onset in separate discrete-time survival model controlling for country, person-years, gender, age-cohort. Person-years were restricted up to and including the first onset of lifetime comorbid disorder.

${ }^{\mathrm{b} R e s p o n d e n t s ~ w i t h ~ l i f e t i m e ~ P A ~ o n s e t ~ t h a t ~ o c c u r s ~} 12$ month of the age of interview were not included in the numerator.

cEach model was estimated using lifetime panic attack as predictor of 12 month comorbid episode among lifetime comorbid disorder cases in separate logistic regression model controlling for country, gender, age-cohort, time since comorbid disorder onset and age of comorbid disorder onset. Respondents with lifetime PA onset that occurs 12 month of the age of interview were not counted as a predictor.

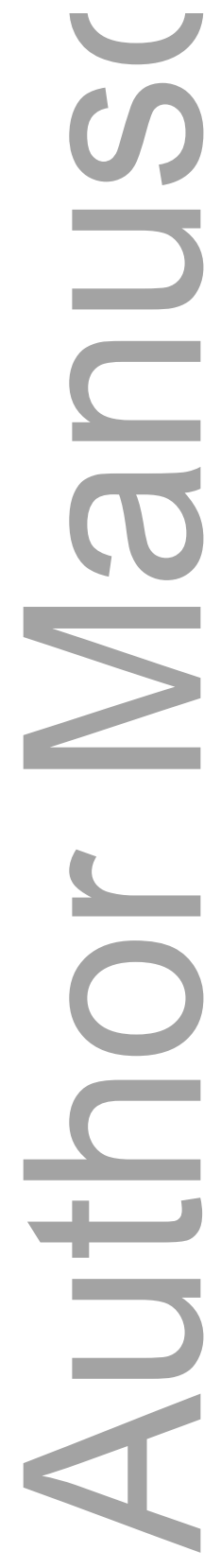

This article is protected by copyright. All rights reserved. 
Appendix Table 1. 12-month prevalence of panic attack (PA) and panic disorder (PD) in the World Mental Health surveys.

\begin{tabular}{|c|c|c|c|c|c|c|c|c|c|c|c|c|}
\hline \multirow{3}{*}{ Country } & \multicolumn{6}{|c|}{ Among the total population } & \multirow{2}{*}{\multicolumn{2}{|c|}{$\begin{array}{c}\text { 12-month PA } \\
\text { among lifetime } \\
\text { PA cases } \\
\text { without } \\
\text { lifetime PD }\end{array}$}} & & & \multirow{3}{*}{$\begin{array}{l}\text { Part } 1 \\
\text { sample } \\
\text { sizes }\end{array}$} & \multirow{3}{*}{$\begin{array}{c}\text { Sample } \\
\text { size } \\
\text { used }^{\mathrm{a}}\end{array}$} \\
\hline & \multicolumn{2}{|c|}{$\begin{array}{c}\text { 12-month PA } \\
\text { with or } \\
\text { without } \\
\text { lifetime PD }\end{array}$} & \multicolumn{2}{|c|}{$\begin{array}{l}\text { 12-month } \\
\text { PA without } \\
\text { lifetime PD } \\
\text { cases }\end{array}$} & \multicolumn{2}{|c|}{$\begin{array}{l}\text { 12-month } \\
\text { PD }\end{array}$} & & & \multicolumn{2}{|c|}{$\begin{array}{c}\text { 12-month PD } \\
\text { among } \\
\text { lifetime PD }\end{array}$} & & \\
\hline & $\%$ & SE & $\%$ & SE & $\%$ & SE & $\%$ & SE & $\%$ & SE & & \\
\hline $\begin{array}{l}\text { Low-Lower middle income } \\
\text { countries }\end{array}$ & 2.9 & 0.1 & 2.4 & 0.1 & 0.5 & 0.1 & 38.4 & 1.3 & 64.4 & 3.6 & 36498 & 36395 \\
\hline Colombia & 6.1 & 0.4 & $5 \cdot 4$ & 0.4 & 0.7 & 0.1 & 31.2 & 2.2 & 53.7 & 9.0 & 4426 & 4422 \\
\hline Iraq & 3.7 & 0.5 & 2.7 & 0.4 & 1.0 & 0.3 & 43.5 & 4.6 & 71.5 & 6.5 & 4332 & 4295 \\
\hline Nigeria & 1.3 & 0.2 & 1.1 & 0.2 & 0.1 & 0.1 & 46.7 & $5 \cdot 3$ & 76.2 & 16.1 & 6752 & 6713 \\
\hline Peru & 3.0 & 0.2 & 2.7 & 0.2 & 0.3 & 0.1 & 40.3 & 2.1 & 70.5 & 6.4 & 3930 & 3929 \\
\hline PRC China & 1.0 & 0.2 & 0.8 & 0.2 & 0.2 & 0.1 & 47.6 & 8.4 & 50.1 & 13.0 & 5201 & 5197 \\
\hline PRC Shen Zhen & 0.9 & 0.1 & 0.7 & 0.1 & 0.2 & 0.1 & 33.4 & 4.1 & 78.9 & 7.7 & 7132 & 7129 \\
\hline Ukraine & 6.2 & 0.4 & 4.8 & 0.3 & 1.4 & 0.3 & 42.6 & 2.4 & 64.4 & 6.2 & 4725 & 4710 \\
\hline Upper-middle income countries & 4.3 & 0.2 & 3.7 & 0.2 & 0.7 & 0.1 & 36.4 & 1.2 & 62.1 & 3.5 & 28927 & 24565 \\
\hline Brazil & 5.1 & 0.3 & 4.0 & 0.3 & 1.0 & 0.2 & 40.2 & 2.2 & 61.8 & 8.2 & 5037 & 5023 \\
\hline Bulgaria & 2.7 & 0.3 & 2.2 & 0.3 & 0.6 & 0.1 & 43.7 & $4 \cdot 4$ & $53 \cdot 5$ & $5 \cdot 4$ & 5318 & 5301 \\
\hline Colombia (Medellin) & 7.1 & 0.7 & 6.1 & 0.6 & 0.9 & 0.2 & 32.6 & 2.4 & 73.8 & 7.2 & 3261 & 3260 \\
\hline Lebanon & 4.8 & 0.5 & 4.6 & 0.5 & 0.3 & 0.1 & 34.1 & 2.7 & 49.2 & 10.3 & 2857 & 2851 \\
\hline Mexico & $3 \cdot 3$ & 0.4 & 2.6 & 0.3 & 0.7 & 0.1 & 38.6 & 3.1 & $65 \cdot 3$ & 7.1 & 5782 & 5781 \\
\hline Romania & 4.7 & 0.4 & 4.2 & 0.4 & 0.4 & 0.1 & 32.0 & $3 \cdot 3$ & 63.3 & 12.1 & 2357 & 2349 \\
\hline High income countries & 6.0 & 0.1 & 4.8 & 0.1 & 1.2 & 0.1 & $33 \cdot 3$ & 0.5 & 55.2 & 1.4 & 81839 & 81754 \\
\hline Australia & $7 \cdot 3$ & 0.4 & $5 \cdot 5$ & 0.4 & 1.8 & 0.2 & 30.8 & 1.7 & 50.0 & 3.9 & 8463 & 8461 \\
\hline Belgium & 3.5 & 0.7 & 2.7 & 0.5 & 0.9 & 0.3 & 31.4 & 4.0 & 54.6 & 11.4 & 2419 & 2417 \\
\hline France & 3.2 & 0.4 & 2.3 & 0.2 & 1.0 & 0.3 & 25.2 & 2.3 & 46.0 & 9.7 & 2894 & 2894 \\
\hline Germany & 3.2 & 0.4 & 2.5 & 0.4 & 0.7 & 0.2 & 28.9 & $3 \cdot 3$ & 46.9 & 7.2 & 3555 & 3555 \\
\hline Israel & 5.0 & 0.3 & 4.4 & 0.3 & 0.6 & 0.1 & 48.7 & 2.5 & 62.6 & 7.5 & 4859 & 4853 \\
\hline
\end{tabular}

This article is protected by copyright. All rights reserved. 


\begin{tabular}{|c|c|c|c|c|c|c|c|c|c|c|c|c|}
\hline Italy & 2.7 & 0.3 & 2.1 & 0.3 & 0.7 & 0.1 & 32.1 & 3.4 & 42.5 & 5.8 & 4712 & 4708 \\
\hline Japan & 2.0 & 0.3 & 1.7 & 0.2 & 0.3 & 0.1 & 28.8 & 3.1 & 45.0 & 10.6 & 4129 & 4126 \\
\hline New Zealand & 9.2 & 0.3 & 7.5 & 0.3 & 1.7 & 0.1 & 30.5 & 1.1 & 60.3 & 3.2 & 12790 & 12781 \\
\hline Northern Ireland & 9.5 & 0.5 & 7.2 & 0.5 & 2.3 & 0.2 & 34.1 & 1.8 & 70.7 & 3.6 & 4340 & 4335 \\
\hline Poland & 2.5 & 0.1 & 2.3 & 0.1 & 0.2 & 0.1 & 41.4 & 2.1 & 62.8 & 8.5 & 10081 & 10049 \\
\hline Portugal & 6.9 & 0.4 & 6.0 & 0.4 & 0.9 & 0.2 & 33.3 & 1.9 & 52.9 & 6.9 & 3849 & 3841 \\
\hline Spain & 3.7 & 0.3 & 3.1 & 0.3 & 0.6 & 0.1 & 36.9 & 2.7 & 49.2 & 6.8 & 5473 & 5472 \\
\hline Spain (Murcia) & 6.0 & 0.5 & $5 \cdot 3$ & 0.6 & 0.7 & 0.1 & 36.3 & 2.7 & 45.7 & 6.5 & 2621 & 2617 \\
\hline The Netherlands & 4.5 & 0.4 & 3.2 & 0.4 & 1.3 & 0.3 & 29.1 & 3.1 & 41.5 & 6.2 & 2372 & 2370 \\
\hline The United States & 10.7 & 0.4 & 8.0 & 0.4 & 2.7 & 0.2 & 35.2 & 1.2 & 57.9 & 3.0 & 9282 & 9275 \\
\hline All countries combined & 4.9 & 0.1 & 4.0 & 0.1 & 1.0 & 0.0 & 34.5 & 0.5 & 57.1 & 1.3 & 147264 & 142714 \\
\hline \multicolumn{13}{|l|}{ WHO regions ${ }^{b}$} \\
\hline Region of the Americas & 6.5 & 0.2 & 5.2 & 0.2 & 1.3 & 0.1 & $35 \cdot 3$ & 0.8 & 60.0 & 2.4 & 31718 & 31690 \\
\hline African Region & 1.3 & 0.2 & 1.1 & 0.2 & 0.1 & 0.1 & 46.7 & 5.3 & 76.2 & 16.1 & 11067 & 6713 \\
\hline Western Pacific Region & 5.3 & 0.2 & 4.2 & 0.1 & 1.1 & 0.1 & 30.9 & 0.9 & 55.4 & 2.4 & 37715 & 37694 \\
\hline \multicolumn{13}{|l|}{ Region } \\
\hline Western European Region & 4.9 & 0.1 & 3.9 & 0.1 & 1.0 & 0.1 & 32.8 & 0.9 & 52.5 & 2.2 & 32235 & 32209 \\
\hline Eastern European Region & 3.6 & 0.1 & 3.0 & 0.1 & 0.6 & 0.1 & 40.4 & 1.4 & 61.1 & 3.8 & 22481 & 22409 \\
\hline $\begin{array}{l}\text { Comparison between } \\
\text { countries }^{c}\end{array}$ & \multicolumn{2}{|c|}{$\begin{aligned} \chi_{27}^{2} & =55.3^{*} \\
P & <.001\end{aligned}$} & \multicolumn{2}{|c|}{$\begin{array}{l}\chi_{27}^{2}= \\
43.8^{*} \\
P<.001\end{array}$} & \multicolumn{2}{|c|}{$\begin{array}{c}\chi_{27}^{2}=15.9^{*} \\
P<.001\end{array}$} & \multicolumn{2}{|c|}{$\begin{array}{c}\chi_{27}^{2}=4.7^{*} \\
P<.001\end{array}$} & \multicolumn{3}{|c|}{$\begin{array}{c}\chi_{27}^{2}=2.1^{*} \\
P=0.001\end{array}$} & \\
\hline $\begin{array}{l}\text { Comparison between low, } \\
\text { middle and high income } \\
\text { country groups }{ }^{c}\end{array}$ & \multicolumn{2}{|c|}{$\begin{aligned} \chi_{2}^{2} & =183.1 * \\
P & <.001\end{aligned}$} & \multicolumn{2}{|c|}{$\begin{array}{l}\chi_{2}^{2}= \\
147.3^{*} \\
P<.001\end{array}$} & \multicolumn{2}{|c|}{$\begin{array}{c}\chi_{2}^{2}=50.8^{*} \\
P<.001\end{array}$} & \multicolumn{2}{|c|}{$\begin{array}{c}\chi_{2}^{2}=8.4^{*} \\
P<.001\end{array}$} & \multicolumn{2}{|c|}{$\begin{array}{l}\chi_{2}^{2}=3.8^{*} \\
P=0.024\end{array}$} & & \\
\hline $\begin{array}{l}\text { Comparison between WHO } \\
\text { regions }^{c}\end{array}$ & \multicolumn{2}{|c|}{$\begin{aligned} \chi_{5}^{2} & =71.7^{*} \\
P & <.001\end{aligned}$} & \multicolumn{2}{|c|}{$\begin{array}{c}\chi_{5}^{2}=52.8^{*} \\
P<.001\end{array}$} & \multicolumn{2}{|c|}{$\begin{aligned} \chi_{5}^{2} & =35.7^{*} \\
P & <.001\end{aligned}$} & \multicolumn{2}{|c|}{$\begin{aligned} \chi_{5}^{2} & =12.4^{*} \\
P & <.001\end{aligned}$} & \multicolumn{2}{|c|}{$\begin{array}{l}\chi_{5}^{2}=2.1 \\
P=0.063\end{array}$} & & \\
\hline
\end{tabular}

${ }^{\text {a}}$ Sample size used after excluding lifetime panic attack cases with missing age of onset.

This article is protected by copyright. All rights reserved. 
${ }^{\mathrm{b}}$ Region of the Americas (Colombia, Mexico, Brazil, Peru, The United States, Medellin); African region (Nigeria); Western Pacific region (PRC Shen Zhen, PRC Beijing and Shanghai, Japan, Australia,New Zealand); Eastern Mediterranean region (Israel, Iraq, Lebanon); Western European region (Belgium, France, Germany, Italy, The Netherlands, Spain, Northern Ireland, Portugal, Murcia); Eastern European region (Romania, Bulgaria, Poland, Ukraine).

${ }^{c}$ Chi-square test of homogeneity to determine if there is variation in prevalence estimates across countries.

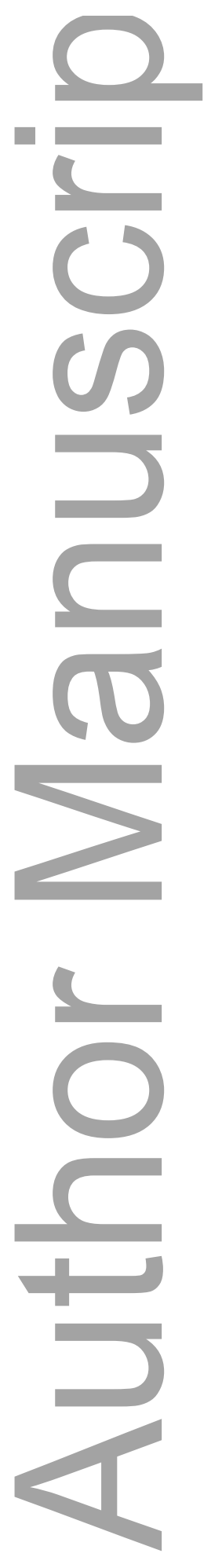

This article is protected by copyright. All rights reserved. 
Appendix Table 2. 30-day prevalence of panic attack (PA) and panic disorder (PD) in the World Mental Health surveys.

\begin{tabular}{|c|c|c|c|c|c|c|c|c|c|c|c|c|}
\hline \multirow{3}{*}{ Country } & \multicolumn{6}{|c|}{ Among the total population } & \multirow{2}{*}{\multicolumn{2}{|c|}{$\begin{array}{l}\text { 30-day PA } \\
\text { among 12- } \\
\text { month PA } \\
\text { cases without } \\
\text { lifetime PD }\end{array}$}} & \multirow{2}{*}{\multicolumn{2}{|c|}{$\begin{array}{l}\text { 30-day PD } \\
\text { among 12- } \\
\text { month PD }\end{array}$}} & \multirow{3}{*}{$\begin{array}{c}\text { Part } 1 \\
\text { sample } \\
\text { sizes }\end{array}$} & \multirow{3}{*}{$\begin{array}{c}\text { Sample } \\
\text { size } \\
\text { used }^{\mathrm{a}}\end{array}$} \\
\hline & \multicolumn{2}{|c|}{ 30-day PA } & \multicolumn{2}{|c|}{$\begin{array}{c}\text { 30-day PA } \\
\text { without } \\
\text { lifetime PD } \\
\text { cases }\end{array}$} & \multicolumn{2}{|c|}{ 30-day PD } & & & & & & \\
\hline & $\%$ & SE & $\%$ & SE & $\%$ & SE & $\%$ & SE & $\%$ & SE & & \\
\hline $\begin{array}{l}\text { Low-Lower middle income } \\
\text { countries }\end{array}$ & 1.0 & 0.1 & 0.8 & 0.1 & 0.3 & 0.0 & 32.4 & 1.9 & 50.4 & 4.7 & 36498 & 36395 \\
\hline Colombia & 1.6 & 0.2 & 1.3 & 0.2 & 0.3 & 0.1 & $24 \cdot 9$ & 3.2 & 44.8 & 10.6 & 4426 & 4422 \\
\hline Iraq & 1.9 & 0.3 & 1.2 & 0.3 & 0.7 & 0.3 & 45.1 & 7.0 & 71.4 & 10.3 & 4332 & 4295 \\
\hline Nigeria & 0.3 & 0.1 & 0.3 & 0.1 & 0.0 & 0.0 & 24.6 & 7.2 & 17.2 & 14.0 & 6752 & 6713 \\
\hline Peru & 0.9 & 0.1 & 0.8 & 0.1 & 0.1 & 0.0 & 30.8 & 4.8 & 35.6 & 13.1 & 3930 & 3929 \\
\hline PRC China & 0.3 & 0.1 & 0.3 & 0.1 & 0.1 & 0.1 & 30.4 & 7.6 & 36.3 & 22.4 & 5201 & 5197 \\
\hline PRC Shen Zhen & 0.3 & 0.1 & 0.3 & 0.1 & 0.1 & 0.0 & 34.6 & $9 \cdot 3$ & 36.1 & 14.6 & 7132 & 7129 \\
\hline Ukraine & 2.5 & 0.3 & 1.8 & 0.2 & 0.7 & 0.2 & 37.1 & 2.9 & 52.4 & 6.3 & 4725 & 4710 \\
\hline Upper-middle income countries & 1.4 & 0.1 & 1.2 & 0.1 & 0.3 & 0.0 & 31.7 & 1.9 & 38.9 & 4.8 & 28927 & 24565 \\
\hline Brazil & 1.7 & 0.2 & 1.3 & 0.2 & 0.4 & 0.1 & 32.9 & 3.6 & 37.0 & 8.8 & 5037 & 5023 \\
\hline Bulgaria & 1.2 & 0.2 & 0.9 & 0.2 & 0.3 & 0.1 & 41.0 & 5.6 & $49 \cdot 4$ & 11.4 & 5318 & 5301 \\
\hline Colombia (Medellin) & 1.7 & 0.3 & 1.4 & 0.2 & 0.3 & 0.1 & 22.9 & 3.6 & 34.1 & 11.1 & 3261 & 3260 \\
\hline Lebanon & 1.5 & 0.3 & 1.4 & 0.3 & 0.1 & 0.1 & 31.0 & 5.0 & 33.0 & 16.4 & 2857 & 2851 \\
\hline Mexico & 1.0 & 0.2 & 0.7 & 0.1 & 0.2 & 0.1 & 28.5 & 4.4 & 30.9 & 8.9 & 5782 & 5781 \\
\hline Romania & 2.1 & 0.3 & 1.8 & 0.3 & 0.3 & 0.1 & 42.2 & 5.9 & 67.6 & 21.2 & 2357 & 2349 \\
\hline High income countries & 1.8 & 0.1 & 1.3 & 0.1 & 0.5 & 0.0 & 27.9 & 0.8 & 39.1 & 2.0 & 81839 & 81754 \\
\hline Australia & 1.9 & 0.2 & 1.3 & 0.2 & 0.6 & 0.1 & $24 \cdot 3$ & 2.6 & 33.0 & 4.9 & 8463 & 8461 \\
\hline Belgium & 1.2 & 0.5 & 0.8 & 0.3 & 0.5 & 0.3 & 28.9 & 8.3 & 50.8 & 15.8 & 2419 & 2417 \\
\hline France & 0.8 & 0.2 & 0.5 & 0.1 & 0.2 & 0.1 & $24 \cdot 3$ & 5.2 & 22.6 & 10.3 & 2894 & 2894 \\
\hline Germany & 1.0 & 0.2 & 0.6 & 0.1 & 0.4 & 0.2 & 23.3 & 4.5 & 53.1 & 12.0 & 3555 & 3555 \\
\hline Israel & 1.4 & 0.2 & 1.3 & 0.2 & 0.2 & 0.1 & 28.3 & 3.2 & 32.8 & 8.8 & 4859 & 4853 \\
\hline
\end{tabular}

This article is protected by copyright. All rights reserved. 


\begin{tabular}{|c|c|c|c|c|c|c|c|c|c|c|c|c|}
\hline Italy & 1.0 & 0.2 & 0.7 & 0.2 & 0.3 & 0.1 & 31.8 & 5.9 & 46.5 & 9.8 & 4712 & 4708 \\
\hline Japan & 0.5 & 0.1 & 0.3 & 0.1 & 0.2 & 0.1 & 20.3 & 5.7 & 46.2 & 14.1 & 4129 & 4126 \\
\hline New Zealand & 2.9 & 0.2 & 2.2 & 0.2 & 0.7 & 0.1 & 29.3 & 1.7 & 41.3 & 3.8 & 12790 & 12781 \\
\hline Northern Ireland & 3.3 & 0.3 & 2.2 & 0.2 & 1.1 & 0.2 & 30.9 & 3.0 & 45.8 & 4.8 & 4340 & 4335 \\
\hline Poland & 0.7 & 0.1 & 0.6 & 0.1 & 0.0 & 0.0 & 26.7 & 3.0 & 19.4 & 9.4 & 10081 & 10049 \\
\hline Portugal & 2.0 & 0.2 & 1.7 & 0.2 & 0.4 & 0.1 & 27.8 & 2.8 & 39.0 & 10.7 & 3849 & 3841 \\
\hline Spain & 1.2 & 0.2 & 1.0 & 0.2 & 0.3 & 0.1 & 30.9 & 4.9 & 47.1 & 7.8 & 5473 & 5472 \\
\hline Spain (Murcia) & 1.6 & 0.4 & 1.4 & 0.3 & 0.2 & 0.1 & 27.0 & 5.0 & 28.2 & 14.3 & 2621 & 2617 \\
\hline The Netherlands & 1.3 & 0.4 & 0.7 & 0.3 & 0.5 & 0.2 & 23.0 & 7.2 & 43.2 & 11.4 & 2372 & 2370 \\
\hline The United States & 3.3 & 0.2 & 2.2 & 0.2 & 1.0 & 0.1 & 28.0 & 1.9 & 38.1 & 4.6 & 9282 & 9275 \\
\hline All countries combined & 1.6 & 0.0 & 1.2 & 0.0 & 0.4 & 0.0 & 29.2 & 0.7 & 40.6 & 1.7 & 147264 & 142714 \\
\hline \multicolumn{13}{|l|}{ WHO regions ${ }^{b}$} \\
\hline Region of the Americas & 1.9 & 0.1 & 1.4 & 0.1 & 0.5 & 0.1 & 27.8 & 1.3 & 37.4 & 3.4 & 31718 & 31690 \\
\hline African Region & 0.3 & 0.1 & 0.3 & 0.1 & 0.0 & 0.0 & 24.6 & 7.2 & 17.2 & 14.0 & 11067 & 6713 \\
\hline Western Pacific Region & 1.6 & 0.1 & 1.2 & 0.1 & 0.4 & 0.0 & 27.7 & 1.4 & 38.0 & 2.9 & 37715 & 37694 \\
\hline Eastern Mediterranean & 1.6 & 0.2 & 1.3 & 0.1 & 0.4 & 0.1 & 33.3 & 2.8 & 53.8 & 7.9 & 12048 & 11999 \\
\hline \multicolumn{13}{|l|}{ Region } \\
\hline Western European Region & 1.5 & 0.1 & 1.1 & 0.1 & 0.4 & 0.0 & 28.5 & 1.5 & 43.0 & 3.2 & 32235 & 32209 \\
\hline Eastern European Region & 1.3 & 0.1 & 1.1 & 0.1 & 0.3 & 0.1 & 34.9 & 1.9 & 47.6 & 5.2 & 22481 & 22409 \\
\hline Comparison between countries ${ }^{c}$ & \multicolumn{2}{|c|}{$\begin{array}{c}\chi_{27}^{2}=22.7^{*} \\
P<.001\end{array}$} & \multicolumn{2}{|c|}{$\begin{array}{c}\chi_{27}^{2}=15.1^{*} \\
P<.001\end{array}$} & \multicolumn{2}{|c|}{$\begin{array}{l}\chi_{27}^{2}= \\
10.2^{*} \\
P<.001\end{array}$} & \multicolumn{2}{|c|}{$\begin{array}{l}\chi_{27}^{2}=1.4 \\
P=0.095\end{array}$} & \multicolumn{3}{|c|}{$\begin{array}{l}\chi_{27}^{2}=1.0 \\
P=0.537\end{array}$} & \\
\hline $\begin{array}{l}\text { Comparison between low, } \\
\text { middle and high income country } \\
\text { groups }{ }^{c}\end{array}$ & \multicolumn{2}{|c|}{$\begin{array}{c}\chi_{2}^{2}=40.9^{*} \\
P<.001\end{array}$} & \multicolumn{2}{|c|}{$\begin{array}{c}\chi_{2}^{2}=29.4^{*} \\
P<.001\end{array}$} & \multicolumn{2}{|c|}{$\begin{aligned} \chi_{2}^{2} & =14.7^{*} \\
P & <.001\end{aligned}$} & \multicolumn{2}{|c|}{$\begin{array}{l}\chi_{2}^{2}=3.6^{*} \\
P=0.028\end{array}$} & \multicolumn{2}{|c|}{$\begin{array}{l}\chi_{2}^{2}=2.1 \\
P=0.119\end{array}$} & & \\
\hline $\begin{array}{l}\text { Comparison between WHO } \\
\text { regions }{ }^{c}\end{array}$ & \multicolumn{2}{|c|}{$\begin{array}{c}\chi_{5}^{2}=37.8^{*} \\
P<.001\end{array}$} & \multicolumn{2}{|c|}{$\begin{aligned} \chi_{5}^{2} & =19.8^{*} \\
P & <.001\end{aligned}$} & \multicolumn{2}{|c|}{$\begin{aligned} \chi_{5}^{2} & =38.3^{*} \\
P & <.001\end{aligned}$} & \multicolumn{2}{|c|}{$\begin{array}{l}\chi_{5}^{2}=2.7^{*} \\
P=0.021\end{array}$} & \multicolumn{2}{|c|}{$\begin{array}{l}\chi_{5}^{2}=1.5 \\
P=0.193\end{array}$} & & \\
\hline
\end{tabular}

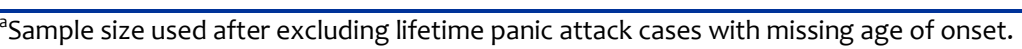

This article is protected by copyright. All rights reserved. 
${ }^{\mathrm{b}}$ Region of the Americas (Colombia, Mexico, Brazil, Peru, The United States, Medellin); African region (Nigeria); Western Pacific region (PRC Shen Zhen, PRC Beijing and Shanghai, Japan, Australia,New Zealand); Eastern Mediterranean region (Israel, Iraq, Lebanon); Western European region (Belgium, France, Germany, Italy, The Netherlands, Spain, Northern Ireland, Portugal, Murcia); Eastern European region (Romania, Bulgaria, Poland, Ukraine).

${ }^{c}$ Chi-square test of homogeneity to determine if there is variation in prevalence estimates across countries.

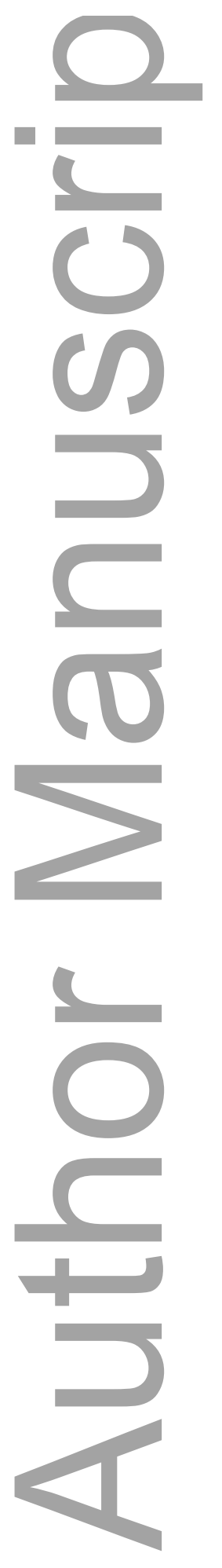

This article is protected by copyright. All rights reserved. 
Appendix Table 3. Comorbidity of panic disorder with other mental disorders.

\begin{tabular}{|c|c|c|c|c|c|c|c|c|c|c|}
\hline & \multicolumn{10}{|c|}{ Panic disorder cases with comorbid disorders } \\
\hline & \multicolumn{2}{|c|}{$\begin{array}{c}\text { Mood } \\
\text { disorder }\end{array}$} & \multicolumn{2}{|c|}{$\begin{array}{l}\text { Anxiety } \\
\text { disorder }\end{array}$} & \multicolumn{2}{|c|}{$\begin{array}{l}\text { Impulse- } \\
\text { control } \\
\text { disorder }\end{array}$} & \multicolumn{2}{|c|}{$\begin{array}{l}\text { Substance- } \\
\text { use disorder }\end{array}$} & \multicolumn{2}{|c|}{$\begin{array}{l}\text { Any mental } \\
\text { disorder }\end{array}$} \\
\hline & $\%$ & SE & $\%$ & SE & $\%$ & SE & $\%$ & SE & $\%$ & SE \\
\hline \multicolumn{11}{|c|}{ Lifetime comorbidity $^{\mathrm{a}}$} \\
\hline Lifetime & 53.7 & 1.4 & 63.1 & 1.3 & 10.4 & 0.7 & 26.2 & 1.4 & 80.4 & 1.1 \\
\hline 12-month & 55.4 & 1.7 & 64.9 & 1.7 & 12.2 & 1.1 & 28.1 & 1.7 & 81.8 & 1.5 \\
\hline \multicolumn{11}{|c|}{ 12-month comorbidity ${ }^{b}$} \\
\hline 12-month & 43.6 & 1.8 & 57.6 & 1.8 & 8.1 & 0.8 & 11.2 & 1.3 & 71.7 & 1.6 \\
\hline \multicolumn{11}{|c|}{ Temporal priority of panic disorder ${ }^{c}$} \\
\hline Lifetime & 33.0 & 1.8 & 15.2 & 1.4 & 36.9 & 3.1 & 45.8 & 3.2 & 15.4 & 0.9 \\
\hline 12-month & 35.1 & 2.2 & 17.3 & 2.0 & 34.4 & 3.4 & 51.1 & 3.8 & 15.7 & 1.3 \\
\hline
\end{tabular}

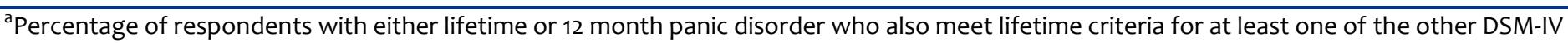
disorders.

This article is protected by copyright. All rights reserved. 
${ }^{\mathrm{b}}$ Percentage of respondents with 12 month panic disorder who also meet 12 month criteria for at least one of the other disorders.

'Percentage of respondents with either lifetime or 12 month panic disorder and at least 1 of the other disorders, whose age of onset of panic disorder is reported to be younger than the age of onset of all comorbid disorders under consideration (ie, either mood, anxiety, substance use, impulse control or any disorder).

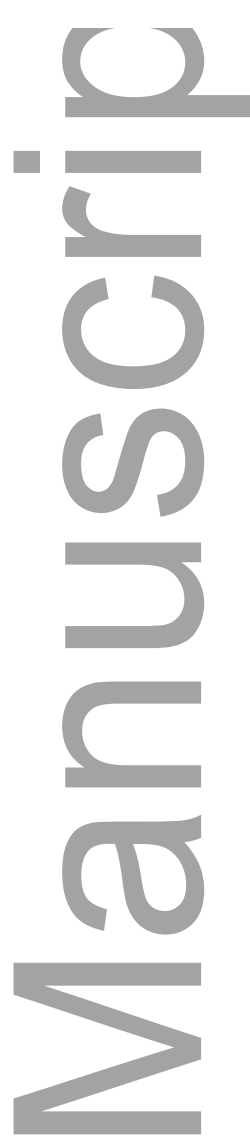

This article is protected by copyright. All rights reserved. 
Appendix Table 4. Bivariate associations between socio-demographics correlates and panic disorder.

\begin{tabular}{|c|c|c|c|c|c|c|c|c|}
\hline \multirow[t]{2}{*}{ Correlates } & \multicolumn{2}{|c|}{$\begin{array}{l}\text { 30-day Panic } \\
\text { Disorder }^{\mathrm{a}}\end{array}$} & \multicolumn{2}{|c|}{$\begin{array}{l}\text { Lifetime Panic } \\
\text { Disorder }^{b}\end{array}$} & \multicolumn{2}{|c|}{$\begin{array}{l}\text { 12-month Panic } \\
\text { Disorder among } \\
\text { lifetime cases }^{c}\end{array}$} & \multicolumn{2}{|c|}{$\begin{array}{l}\text { 30-day Panic } \\
\text { Disorder among 12- } \\
\text { month cases }\end{array}$} \\
\hline & OR & $(95 \% \mathrm{Cl})$ & OR & $(95 \% \mathrm{Cl})$ & OR & $(95 \% \mathrm{Cl})$ & OR & $(95 \% \mathrm{Cl})$ \\
\hline \multicolumn{9}{|l|}{ Age-cohort } \\
\hline $18-29$ & $1.7^{*}$ & $(1.2-2.4)$ & $6.4^{*}$ & $(5.2-7.7)$ & & & & \\
\hline $30-44$ & $2.0^{*}$ & $(1.5-2.6)$ & $5.0^{*}$ & $(4.2-5.8)$ & & & & \\
\hline $45-59$ & $1.6^{*}$ & $(1.2-2.1)$ & $3.0^{*}$ & $(2.6-3.6)$ & & & & \\
\hline $60+$ & 1.0 & & 1.0 & & & & & \\
\hline \multirow[t]{2}{*}{ Age-cohort difference $^{d}$} & & $\begin{array}{l}24.5^{*} \\
.001\end{array}$ & \multicolumn{2}{|c|}{$\begin{array}{c}\chi_{3}^{2}=455.2^{*}, \\
P<.001\end{array}$} & \multicolumn{2}{|r|}{$\square$} & & $\square$ \\
\hline & & & $\square$ & & $\square$ & & $\square$ & \\
\hline \multicolumn{9}{|l|}{ Age of onset } \\
\hline Early & & & & & $2.2^{*}$ & $(1.6-3.0)$ & 1.2 & $(0.8-1.7)$ \\
\hline Early-average & & & & & 1.3 & $(0.9-1.7)$ & 1.2 & $(0.8-1.8)$ \\
\hline Late-average & & & & & 0.9 & $(0.7-1.1)$ & 0.9 & $(0.6-1.3)$ \\
\hline Late & & & & & 1.0 & & 1.0 & \\
\hline Age of onset difference ${ }^{d}$ & & & & & $\chi$ & $\begin{array}{l}=34.7^{*}, \\
<.001\end{array}$ & & $\begin{array}{l}=3.0 \\
=0.387\end{array}$ \\
\hline \multirow[t]{3}{*}{ Time since onset (Continuous) } & & & & & $0.98^{*}$ & $(0.97-0.99)$ & 1.00 & $(0.99-1.01)$ \\
\hline & & & & & \multicolumn{2}{|c|}{$\begin{array}{c}\chi_{1}^{2}=23.6^{*}, \\
P<.001\end{array}$} & \multicolumn{2}{|c|}{$\begin{array}{l}\chi_{1}^{2}=0.2, \\
P=0.655\end{array}$} \\
\hline & & & $\square$ & & $\square$ & & $\square$ & \\
\hline \multicolumn{9}{|l|}{ Gender } \\
\hline Female & $2.0^{*}$ & $(1.6-2.5)$ & $1.8^{*}$ & $(1.6-2.0)$ & 1.2 & $(1.0-1.5)$ & 1.0 & $(0.7-1.3)$ \\
\hline Male & 1.0 & & 1.0 & & 1.0 & & 1.0 & \\
\hline Gender difference $^{d}$ & & $\begin{array}{l}35.0^{*} \\
.001\end{array}$ & & $\begin{array}{l}\text { 109.0*, } \\
<.001\end{array}$ & & $\begin{array}{l}=3.4 \\
0.064\end{array}$ & & $\begin{array}{l}=0.0 \\
0.956\end{array}$ \\
\hline \multicolumn{9}{|l|}{ Employment status } \\
\hline Student & 1.1 & $(0.6-2.0)$ & 1.3 & $(0.9-1.8)$ & 1.8 & $(0.9-3.8)$ & 1.0 & $(0.4-2.1)$ \\
\hline
\end{tabular}

This article is protected by copyright. All rights reserved. 


\begin{tabular}{|c|c|c|c|c|c|c|c|c|}
\hline Homemaker & $1.4^{*}$ & $(1.0-2.0)$ & $1.4^{*}$ & $(1.2-1.6)$ & $1.5^{*}$ & $(1.1-2.0)$ & 0.8 & $(0.5-1.2)$ \\
\hline Retired & 1.1 & $(0.8-1.6)$ & $1.3^{*}$ & $(1.0-1.6)$ & $1.5^{*}$ & $(1.0-2.2)$ & 1.1 & $(0.7-1.8)$ \\
\hline Other & $3.0^{*}$ & $(2 \cdot 3-4.1)$ & $2.0^{*}$ & $(1.7-2.4)$ & $2.2^{*}$ & $(1.6-3.2)$ & $1.5^{*}$ & $(1.0-2.1)$ \\
\hline Employed & 1.0 & & 1.0 & & 1.0 & & 1.0 & \\
\hline Employment status difference $^{d}$ & & $\begin{array}{l}57.5^{*}, \\
.001\end{array}$ & & $\begin{array}{l}84.2 * \text {, } \\
.001\end{array}$ & & $\begin{array}{l}25.4^{*}, \\
.001\end{array}$ & & $\begin{array}{l}=6.3 \\
0.182\end{array}$ \\
\hline \multicolumn{9}{|l|}{ Marital status } \\
\hline Never married & 1.1 & $(0.8-1.4)$ & $1.3^{*}$ & $(1.2-1.5)$ & 1.2 & $(0.9-1.6)$ & 1.2 & $(0.8-1.7)$ \\
\hline Divorced/separated/widowed & $2.6^{*}$ & $(2.0-3.4)$ & $1.7^{*}$ & $(1.5-1.9)$ & $1.6^{*}$ & $(1.2-2.1)$ & $1.5^{*}$ & $(1.1-2.1)$ \\
\hline Currently married & 1.0 & & 1.0 & & 1.0 & & 1.0 & \\
\hline Marital status difference $^{d}$ & & $\begin{array}{l}48.8^{*} \text {, } \\
.001\end{array}$ & & $\begin{array}{l}77.4 *, \\
.001\end{array}$ & & $\begin{array}{l}12.9^{*} \\
.002\end{array}$ & & $\begin{array}{l}=6.2 * \\
0.044\end{array}$ \\
\hline \multicolumn{9}{|l|}{ Education level } \\
\hline No education & $3.8^{*}$ & $(1.3-11.4)$ & 1.6 & $(0.9-2.6)$ & $4.2^{*}$ & $(1.8-10.2)$ & 2.3 & $(0.8-6.9)$ \\
\hline Some primary & $5.7^{*}$ & $(3.6-8.9)$ & $1.8^{*}$ & $(1.4-2.2)$ & $2.9^{*}$ & $(1.7-5.0)$ & $4.0^{*}$ & $(2.2-7 \cdot 5)$ \\
\hline Finished primary & $5.0^{*}$ & $(2.9-8.6)$ & $2.2^{*}$ & $(1.8-2.8)$ & $1.7^{*}$ & $(1.1-2.6)$ & $2.6^{*}$ & $(1.5-4.7)$ \\
\hline Some secondary & $2.9^{*}$ & $(2.0-4.1)$ & $1.8^{*}$ & $(1.5-2.1)$ & $1.5^{*}$ & $(1.0-2.1)$ & $2.0^{*}$ & $(1.3-3 \cdot 0)$ \\
\hline Finished secondary & $2.6^{*}$ & $(1.8-3.8)$ & $1.7^{*}$ & $(1.4-1.9)$ & 1.3 & $(0.9-1.8)$ & $1.8^{*}$ & $(1.2-2.8)$ \\
\hline Some college & $2.0^{*}$ & $(1.4-2.8)$ & $1.5^{*}$ & $(1.3-1.8)$ & 0.9 & $(0.7-1.3)$ & $1.8^{*}$ & $(1.2-2.8)$ \\
\hline Finished college & 1.0 & & 1.0 & & 1.0 & & 1.0 & \\
\hline Education level difference $^{d}$ & & $\begin{array}{l}66.4^{*} \text {, } \\
.001\end{array}$ & & $\begin{array}{l}65.0 * \\
.001\end{array}$ & & $\begin{array}{l}28.7^{*}, \\
.001\end{array}$ & & $\begin{array}{l}23.4^{*}, \\
0.001\end{array}$ \\
\hline \multicolumn{9}{|l|}{ Household income } \\
\hline Low & $1.8^{*}$ & $(1.3-2.4)$ & $1.5 *$ & $(1.3-1.7)$ & $1.5 *$ & $(1.1-2.1)$ & 1.2 & $(0.8-1.8)$ \\
\hline Low-average & 1.3 & $(1.0-1.8)$ & $1.2 *$ & $(1.1-1.4)$ & 1.3 & $(0.9-1.7)$ & 1.0 & $(0.7-1.5)$ \\
\hline High-average & 1.1 & $(0.8-1.5)$ & 1.1 & $(1.0-1.3)$ & 0.9 & $(0.7-1.3)$ & 1.0 & $(0.7-1.5)$ \\
\hline High & 1.0 & & 1.0 & & 1.0 & & 1.0 & \\
\hline Household income difference $^{d}$ & \multicolumn{2}{|c|}{$\begin{array}{c}\chi_{3}^{2}=21.7^{*} \\
P<.001\end{array}$} & \multicolumn{2}{|c|}{$\begin{array}{c}\chi_{3}^{2}=38.7^{*} \\
P<.001\end{array}$} & \multicolumn{2}{|c|}{$\begin{array}{c}\chi_{3}^{2}=11.3^{*} \\
P=0.010\end{array}$} & \multicolumn{2}{|c|}{$\begin{array}{l}\chi_{3}^{2}=2.1 \\
P=0.554\end{array}$} \\
\hline
\end{tabular}

This article is protected by copyright. All rights reserved. 
*Significant at the .05 level, 2 sided test.

${ }^{\mathrm{a}}$ These estimates are based on logistic regression models adjusted for age, gender and country.

${ }^{\mathrm{b}}$ These estimates are based on survival models adjusted for age-cohorts, gender, person-years and country.

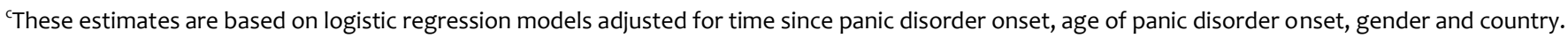

${ }^{\mathrm{d}}$ Chi square test of significant differences between blocks of sociodemographic variables.

${ }^{\mathrm{e}}$ Denominator N: 142,949 = total sample; $6,250,338$ = number of person-years in the survival models; $2,563=$ number of lifetime cases of panic disorder; $1,465=$ number of 12-month cases of panic disorder.

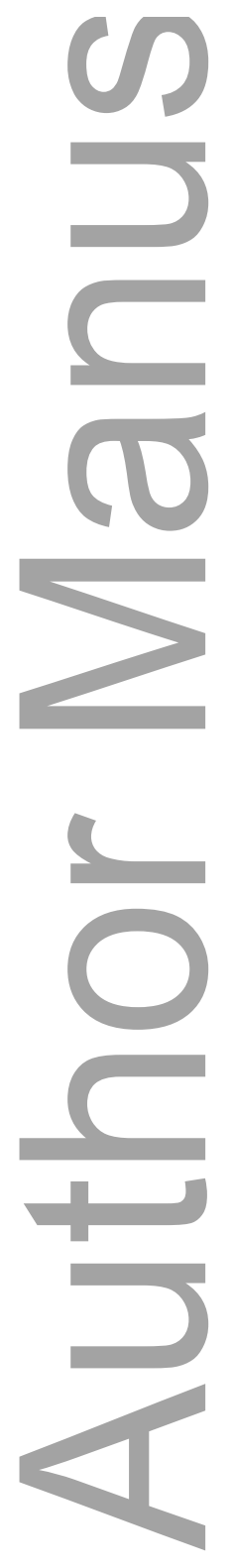

This article is protected by copyright. All rights reserved. 
Appendix Table 5. Bivariate associations between socio-demographics correlates and recurrent panic attacks.



This article is protected by copyright. All rights reserved. 


\begin{tabular}{|c|c|c|c|c|c|c|c|c|}
\hline \multicolumn{9}{|l|}{ Employment status } \\
\hline Student & 1.1 & $(0.8-1.5)$ & 1.1 & $(1.0-1.3)$ & 1.2 & $(0.9-1.5)$ & 1.0 & $(0.7-1.5)$ \\
\hline Homemaker & $1.3^{*}$ & $(1.1-1.6)$ & 1.1 & $(1.0-1.1)$ & 1.2 & $(1.0-1.3)$ & 1.2 & $(0.9-1.5)$ \\
\hline Retired & 1.0 & $(0.8-1.3)$ & 1.0 & $(0.9-1.1)$ & $1.4^{*}$ & $(1.2-1.6)$ & 0.8 & $(0.6-1.1)$ \\
\hline Other & $1.9^{*}$ & $(1.6-2.3)$ & $1.4^{*}$ & $(1.3-1.5)$ & $1.7^{*}$ & $(1.5-2.0)$ & 1.1 & $(0.9-1.3)$ \\
\hline Employed & 1.0 & & 1.0 & & 1.0 & & 1.0 & \\
\hline Employment status difference $^{d}$ & & $\begin{array}{l}45.5^{*}, \\
.001\end{array}$ & & $\begin{array}{l}86.7^{*}, \\
.001\end{array}$ & & $\begin{array}{l}56.0^{*}, \\
.001\end{array}$ & & $\begin{array}{l}=4.5, \\
=0.340\end{array}$ \\
\hline \multicolumn{9}{|l|}{ Marital status } \\
\hline Never married & 1.1 & $(0.9-1.3)$ & $1.1^{*}$ & $(1.0-1.2)$ & $1.1^{*}$ & $(1.0-1.3)$ & $1.2^{*}$ & $(1.0-1.5)$ \\
\hline Divorced/separated/widowed & $1.4^{*}$ & $(1.2-1.7)$ & $1.2^{*}$ & $(1.1-1.3)$ & $1.2^{*}$ & $(1.1-1.3)$ & 1.1 & $(0.9-1.3)$ \\
\hline Currently married & 1.0 & & 1.0 & & 1.0 & & 1.0 & \\
\hline Marital status difference $^{d}$ & & $\begin{array}{l}18.4^{*}, \\
.001\end{array}$ & & $\begin{array}{l}37.6 * \\
.001\end{array}$ & & $\begin{array}{l}10.9^{*}, \\
0.004\end{array}$ & & $\begin{array}{l}=4.1, \\
=0.129\end{array}$ \\
\hline \multicolumn{9}{|l|}{ Education level } \\
\hline No education & $2.5^{*}$ & $(1.5-4.2)$ & $1.7^{*}$ & $(1.4-2.0)$ & $1.7^{*}$ & $(1.1-2.5)$ & 1.3 & $(0.7-2.3)$ \\
\hline Some primary & $1.9^{*}$ & $(1.5-2.5)$ & $1.5^{*}$ & $(1.4-1.7)$ & $2.0^{*}$ & $(1.6-2.5)$ & 0.8 & $(0.6-1.2)$ \\
\hline Finished primary & $2.0^{*}$ & $(1.5-2.6)$ & $1.4^{*}$ & $(1.3-1.6)$ & $1.8^{*}$ & $(1.5-2.2)$ & 1.0 & $(0.7-1.4)$ \\
\hline Some secondary & $1.5^{*}$ & $(1.2-1.9)$ & $1.2^{*}$ & $(1.1-1.3)$ & $1.4^{*}$ & $(1.2-1.6)$ & 1.0 & $(0.8-1.3)$ \\
\hline Finished secondary & $1.3^{*}$ & $(1.1-1.6)$ & $1.2^{*}$ & $(1.1-1.3)$ & $1.3^{*}$ & $(1.1-1.4)$ & 1.0 & $(0.8-1.2)$ \\
\hline Some college & 1.2 & $(1.0-1.6)$ & $1.2^{*}$ & $(1.1-1.3)$ & $1.2^{*}$ & $(1.0-1.4)$ & 1.0 & $(0.8-1.3)$ \\
\hline Finished college & 1.0 & & 1.0 & & 1.0 & & 1.0 & \\
\hline Education level difference $^{d}$ & & $\begin{array}{l}42.4^{*}, \\
.001\end{array}$ & & $\begin{array}{l}100.7^{*}, \\
.001\end{array}$ & & $\begin{array}{l}55.5^{*} \\
.001\end{array}$ & & $\begin{array}{l}6=3.1, \\
=0.800\end{array}$ \\
\hline \multicolumn{9}{|l|}{ Household income } \\
\hline Low & $1.6^{*}$ & $(1.3-2.0)$ & $1.1^{*}$ & $(1.0-1.2)$ & $1.5^{*}$ & $(1.3-1.7)$ & $1.4^{*}$ & $(1.1-1.7)$ \\
\hline Low-average & $1.4^{*}$ & $(1.1-1.7)$ & $1.1^{*}$ & $(1.0-1.2)$ & $1.2^{*}$ & $(1.1-1.4)$ & 1.2 & $(0.9-1.5)$ \\
\hline High-average & $1.4^{*}$ & $(1.1-1.7)$ & 1.0 & $(1.0-1.1)$ & $1.2^{*}$ & $(1.0-1.3)$ & 1.3 & $(1.0-1.6)$ \\
\hline
\end{tabular}

This article is protected by copyright. All rights reserved. 


$$
\chi_{3}^{2}=20.4^{*}
$$$$
\mathrm{P}<.001
$$

$\chi_{3}^{2}=7.7$,

$\mathrm{P}=0.053$

138281 $\chi_{3}^{2}=31.7^{*}$,

$\mathrm{P}<.001$

$\mathrm{P}=0.087$

$\mathbf{N}^{\mathrm{e}}$

*Significant at the .05 level, 2 sided test.

${ }^{\mathrm{a}}$ These estimates are based on logistic regression models adjusted for age, gender and country.

${ }^{\mathrm{b}}$ These estimates are based on survival models adjusted for age-cohorts, gender, person-years and country.

'These estimates are based on logistic regression models adjusted for time since panic attack onset, age of panic attack onset, gender and country.

${ }^{\mathrm{d} C h i ~ s q u a r e ~ t e s t ~ o f ~ s i g n i f i c a n t ~ d i f f e r e n c e s ~ b e t w e e n ~ b l o c k s ~ o f ~ s o c i o d e m o g r a p h i c ~ v a r i a b l e s . ~}$

${ }^{e}$ Denominator N: 138,281 = total sample; 5,843,592 = number of person-years in the survival models; 12,730 = number of lifetime panic attack without lifetime panic disorder cases; 4,971 = number of 12-month panic attack without lifetime panic disorder cases.

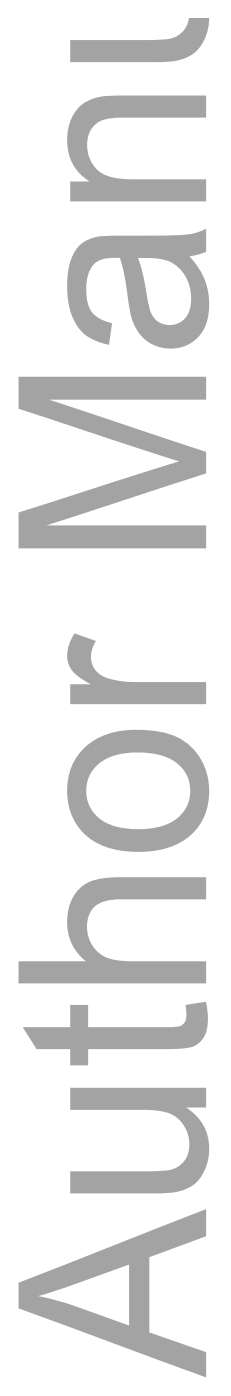

This article is protected by copyright. All rights reserved. 


\section{University Library}

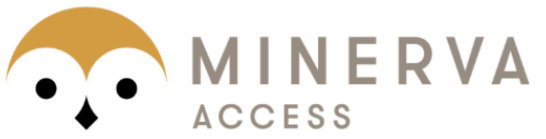

A gateway to Melbourne's research publications

Minerva Access is the Institutional Repository of The University of Melbourne

\section{Author/s:}

de Jonge, P;Roest, AM;Lim, CCW;Florescu, SE;Bromet, EJ;Stein, DJ;Harris, M;Nakov, V;Miguel Caldas-de-Almeida, J;Levinson, D;Al-Hamzawi, AO;Maria Haro, J;Viana, MC;Borges, G;O'Neill, S;de Girolamo, G;Demyttenaere, K;Gureje, O;Iwata, N;Lee, S;Hu, C;Karam, A;Moskalewicz, J;Kovess-Masfety, V;Navarro-Mateu, F;Browne, MO;Piazza, M;Posada-Villa, J;Torres, Y;ten Have, ML;Kessler, RC;Scott, KM

Title:

Cross-national epidemiology of panic disorder and panic attacks in the world mental health surveys

Date:

2016-12-01

\section{Citation:}

de Jonge, P., Roest, A. M., Lim, C. C. W., Florescu, S. E., Bromet, E. J., Stein, D. J., Harris, M., Nakov, V., Miguel Caldas-de-Almeida, J., Levinson, D., Al-Hamzawi, A. O., Maria Haro, J., Viana, M. C., Borges, G., O'Neill, S., de Girolamo, G., Demyttenaere, K., Gureje, O., Iwata, N. ,... Scott, K. M. (2016). Cross-national epidemiology of panic disorder and panic attacks in the world mental health surveys. DEPRESSION AND ANXIETY, 33 (12), pp.1155-1177. https://doi.org/10.1002/da.22572.

Persistent Link:

http://hdl.handle.net/11343/291871 